\title{
EFFECT OF SOME SAFETY GROWTH STIMULANTS AND ZINC TREATMENTS ON GROWTH, SEEDS YIELD, CHEMICAL CONSTITUENTS, OIL PRODUCTIVITY AND FIXED OIL CONSTITUENTS OF CHIA (SALVIA HISPANICA L.) PLANT
}

\author{
Y.F.Y. Mohamed and Y.A.A. Ghatas \\ Horticulture Department, Faculty of Agriculture, Benha University, Egypt
}

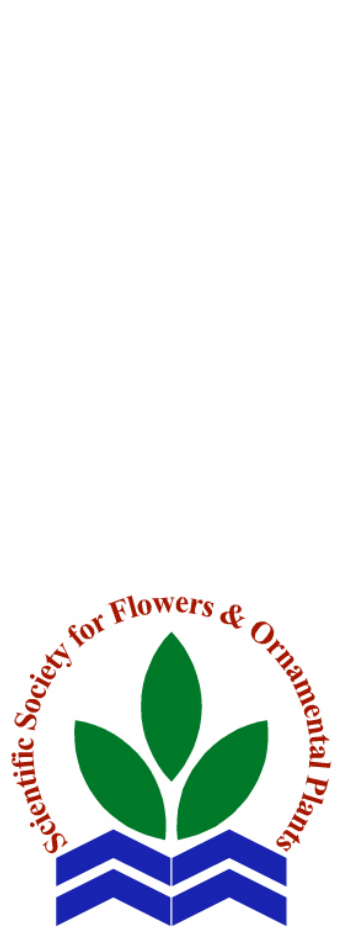

Scientific J. Flowers \& Ornamental Plants, 7(2):163-183 (2020).

Received: 4/6/2020

Accepted: 24/6/2020

\begin{abstract}
This study was carried out at the Experimental Farm and in the Laboratories of Horticulture Departments, Faculty of Agriculture at Moshtohor, Benha Univ., during 2018/2019 and 2019/2020 seasons. The aim of this study was to investigate the possibility of improving growth, seeds yield, oil productivity and fixed oil constituents of chia (Salvia hispanica L.) plants by some safety growth stimulants treatments i.e. chitosan, ascobien, humic and glutamic acids and micronutrients zinc (Zn) i.e., control (tap water), 100 and 200 ppm, as well as their combinations. Plants were sprayed with safety growth stimulants gave the significantly highest mean values for all studied characteristics i.e., plant height, number of branches per plant, plant fresh and dry weights, seeds yield/plant, weight of 1000 seeds, chlorophyll a, b, carotenoids, N, P, K, total carbohydrates, fixed oil percentage, and fatty acids determination of chia (Salvia hispanica L.) plants, with superior for humic acid at $5 \mathrm{ml} / \mathrm{l}$ followed by glutamic acid at $200 \mathrm{ppm}$ in the first and second seasons. Meanwhile, ascobien at $200 \mathrm{ppm}$ ranked the third values in this concern. Irrespective of control plants the lowest values of these parameters were scored by chitosan at $5 \mathrm{~g} / \mathrm{l}$ in the $1^{\text {st }}$ and $2^{\text {nd }}$ seasons. As for zinc concentration treatments, there was appositive relationship between the values of abovementioned parameters and zinc concentration, hence as the concentration of zinc increased the values of these parameters increased till reached the highest increases at the highest concentration (200 ppm) in the two seasons. Furthermore, the combination of humic acid at $5 \mathrm{ml} / \mathrm{l}$ showed to be the most effective one for inducing the highest values of these parameters especially those sprayed with the highest concentration of zinc (200 ppm). Chromatography analysis of chia fixed oil revealed the identification of seven components. The main component was $\alpha$-linolenic acid (37.28 to $39.72 \%$ ). The major components were $\alpha$-linolenic acid, linoleic acid, oleic acid and palmitic acid. It can be concluded that humic acid at $5 \mathrm{~m} / \mathrm{l}$ with $\mathrm{Zn}$ at $200 \mathrm{ppm}$ was the best treatment for improving growth, seeds yield, fixed oil productivity, chemical constituents and fixed oil components of chia (Salvia hispanica L.) plant.
\end{abstract}

Key words: Salvia hispanica, chia, fixed oil, humic acid, glutamic acid, ascobien, chitosan, zinc, oil productivity and GLC. 


\section{INTRODUCTION}

Chia (Salvia hispanica L.) belongs to the Lamiaceae Family and is found mainly in Mexico and northern Guatemala. It is an annual, summery and oleaginous plant (Ayerza and Coates, 2009). Salvia hispanica L. is one of the basic foods of Central American civilizations, in pre-Columbian times (Ayerza and Coates, 2005). Also, $\alpha$ linolenic acid (omega-3), which is one of the most famous botanical oil, is found in a very large amount within the chia, where the chia plant is rich in large quantities (Ayerza, 2013). Chia is an oil seed crop with potential use as human food (Zanqui et al., 2015 and Coorey et al., 2012). Given its tolerance to growth in arid environments, it is preferred to the used as a suitable crop as an alternative to the main crop industry (Peiretti and Gai, 2009). Because, Salvia hispanica is considered a healthy and very suitable food for humans, it was spread and expanded cultivation in African countries, because it provides the body with the necessary healthy and beneficial ingredients (Ayerza and Coates, 2000).

The growth of the Chia plant reaches 1 $\mathrm{m}$ and has leaves present in a reverse arrangement, and its flowers are small (3 - 4 $\mathrm{mm}$ ) with small corollas, and fused flower parts, which results in an increase in the completion of the self-pollination rate. Salvia hispanica seeds contain important compounds, as these seeds are very rich in protein in addition to dietary fibers and oils that have percentages from 25 to $40 \%$, as well as $60-68 \%$ of oil contains (omega) $\omega-3$ $\alpha$-linolenic acid (ALA), in addition to $20 \%$ of omega $\omega-6$ linoleic acid. The seed ranges from 1 to $2 \mathrm{~mm}$, oval in shape, different colors, from black, gray, and black spotted to white. (Cahill and Provance 2002; Peiretti and Meineri 2008; Reyes-Caudillo et al., 2008; Bresson et al., 2009 and Ayerza, 2013). Moreover, the main components of Chia seeds are protein with a ratio (15-25\%), fats $(30-33 \%)$ as well as carbohydrates (26$41 \%)$, high dietary fiber (18-30\%) and ash
(4-5\%), in addition to some minerals, vitamins and dry matter that range from 90 to $93 \%$ and many studies have shown that it contains a good amount of antioxidants (Ixtaina et al., 2008).

Chitosan is a natural biopolymer and influences the stimulation and increased absorption of nutrients, which in turn reflects on the general case in plants, in addition to the work to increase the content of chlorophyll, increase photosynthetic and chloroplast enlargement, also stimulates the plant to produce secondary metabolites such as polyphenols, lignin and flavonoids (Hadwiger, 2013; Malekpoor et al., 2016 and Salachna et al., 2017). The effect of chitosan on the growth and productivity of the plant is probably due to the methods of facilitating the absorption of water and essential nutrients, and it comes by affecting the increased activity of enzymes and adjusting cell osmotic pressure (Guan et al., 2009). In this context, chitosan increased key enzymes activities of nitrogen metabolism and improved the transportation of nitrogen (Gornik et al., 2008). El-Khateeb et al. (2017) showed that the use of chitosan and humic acid in addition to brassinolide led to obtaining the best growth and oil productivity. Also, the use of high concentrations of these substances led to an increase in the oil percentage and yield/ marjoram plant.

Ascobien compound, (25\% ascorbic acid, $13 \%$ citric acid and 62\% organic materials), importance comes in that it contains ascorbic, citric acids, where they play an important role in physiological processes such as regulating growth and metabolism of the plants. In this context, Abdossi and Danaee (2019) stated that ascorbic, citric acids application maximized cell division, growth, and preservation of cell, which affected on the regulation of growth flowering, physiological processes and chemical components on carnation plant.

Humic acid is one of the natural growth bio stimulants as is considered an important 
component of organic substances in aquatic systems. Humic acid (HA) has a great importance for the plant in terms of its effect on growth and clear importance to the soil as it works to improve the properties of the soil and increase the rate of microbial activity as enhances the absorption of many nutrients as a chelating agent. On the other hand, HA activates microorganisms in the soil and works to increase humic and organic matter, especially in alkaline soils containing little organic matter. It is known that humic materials increase the activity of root growth such as auxins, which in turn is reflected in the increased growth of the plant in various stages, and leaf pigments (Berlyn and Russo, 1990)

Amino acids have a great and clear importance as they are considered a major component of proteins and have a great importance within the plant, where they work to affect the activity of many enzymes , gene expression, and have a great organizational importance in plants, increase growth in various stages within the plants (Rai, 2002). Glutamic acid is important metabolic cycles of the plant, the carbon and nitrogen cycles and has an influence on sugars and protein, as well as synthesis of the auxins and fruit set (Taiz and Zeiger, 2002). Many studies have that foliar application of amino acids caused increases in the growth and development of plants. In this respect, Omer et al. (2013) on chamomile plant, Mohamed et al. (2016) on Ocimum basilicum L.) cv. Genovese and Mahdy et al. (2019) on roselle declared that, the high values of growth components (plant height, number of branches, dry weight of leaves and leaf area) and yield parameters (seed yield per plant, fixed oil per plant and fixed oil yield) could be obtained under high level of amino acid (1000 ppm) and combined with third level of cytokinin (60 ppm).

Zinc (Zn) is regarded as an important micronutrient, the shortage of which among many plants is a common issue (OjedaBarrios et al., 2014). It is necessary for the activity of such enzymes as dehydrogenase, aldolase, isomerase, trans phosphorylase, RNA and DNA polymerase. It also playsa part in tryptophan synthesis, cell division, cell structure preservation and photosynthesis. As a cofactor, it gives rise to the synthesis of proteins, because of its role as a cofactor in many proteins (Marschner, 2012). Many of the submitted studies show the importance of using applied micronutrients as foliar spray and their effect on stimulating and increasing the vegetative growth, flowering and chemical components of medicinal and aromatic plants; Yadegari (2015) on borago, thyme and marigold, Abou-Shleell (2017) on Moringa olifera. Ghatas and Mohamed (2018) on Cymbopgon citratus, and Adib et al. (2020) on cumin showed that foliar application of Fe, Zn and sulfur fertilizer improved the injurious effects of water deficiency, through alteration in yield and biochemical characteristics.

For this reason, the aim of this study was to evaluate the effect of using some safety growth biostimulant treatments i.e. chitosan, ascobien, humic acid, amino acid as (glutamic acid) and mico-nutrients zinc (Zn) as well as their combinations as foliar spray on growth, seeds yield, chemical constituents, oil productivity and fixed oil constituents of Salvia hispanica L. plant.

\section{MATERIAL AND METHODS}

This study was carried out at the Experimental Farm and in the Laboratories of Horticulture Departments, Faculty of Agriculture at Moshtohor, Benha Univ., during 2018/2019 and 2019/2020 seasons to study the effect of some safety growth stimulants treatments i.e. chitosan, ascobien, humic and glutamic acids and one of micronutrients zinc (Zn) as well as their combinations on vegetative growth, essential oil productivity and some chemical constituents of chia (Salvia hispanica L.) plant.

Chia seeds were obtained from Floriculture Farm, Horticulture Department, 
Faculty of Agriculture at Moshtohor, Benha Univ. Seeds of chia (1000 seeds weight of $1.25 \mathrm{~g}$ ) were sown in a clay loam soils on mid-October in both seasons in plots $(1 \times 1$ $\mathrm{m})$ containing two rows (50 $\mathrm{cm}$ in between) every row had two hills (50 cm apart) and six weeks later, the plants were thinned, leaving only two seedlings/hill.

Physical and chemical analysis of the experimental soil were determined according to Jackson (1973) and Black et al. (1982), respectively. The obtained results of soil analysis are presented in Table (1).

The layout of the experiment was a factorial complete randomized block design. The first factor involving five growth stimulants treatments, whereas the second factor was devoted to three levels of zinc sprays. Therefore, the experiment included 15 treatments with three replicates, each replicate contained 5 plants i.e. 15 plants in each treatment.

\section{Safety growth stimulants treatments:}

\section{Control (tap water).}

2. Chitosan at $5 \mathrm{~g} / \mathrm{l}$ for each as foliar spray. It is a commercial product by Oxford Laboratory India, includes chitosan 9095\% (2 - Amino - 2 - deoxy - beta - D glucosamine).

3. Ascobien (13\% citric acid $+25 \%$ ascorbic acid $+62 \%$ organic materials) at $200 \mathrm{ppm}$ for each as foliar spray.

4. Humic acid at $5 \mathrm{ml} / \mathrm{l}$ as a foliar spray, it is a commercial product by Leili Agrochemistry Co. Ltd. It includes humic acid at $80 \%-\mathrm{K}_{2} \mathrm{O}$ at $11-13 \%$ and Moisture at 5-7\%.

5. Amino acids (Glutamic acid at $200 \mathrm{ppm}$ ).

The safety growth stimulants were applied as a foliar spray on plant leaves 4 times, first one was added after 45 days from seeds sowing. The second time was after 15 days from the first, while the third was applied after 15 days from the second and the fourth was after 15 days from the third. Spraying was done to the run from the plant foliage.

6. Zinc treatments: three levels of zinc sprays i.e. control (tap water), 100 and 200 ppm, spray in early morning was applied four times at 60, 75, 90 and 105 days after sowing date of the two seasons. Bio-film at $1 \mathrm{ml} / \mathrm{l}$ as a wetting agent, was added to all tested solutions including the control.

The plants were sprayed with the abovementioned treatments by a hand pump mister to the point of runoff. Common agricultural practices (irrigation, fertilization, manual weed control, ... etc.) were carried out when needed.

\section{Harvesting:}

The plants were harvested on $1^{\text {st }}$ March in the first and second seasons.

\section{Data recorded:}

The vegetative and yield parameters were measured and recorded at harvesting time in the $1^{\text {st }}$ March 2019 and 2020 as follows: The vegetative parts were cut about $1 \mathrm{~cm}$ above the soil surface. Measurements of the following traits were collected:

Table 1. Mechanical and chemical analysis of the experimental soil.

\begin{tabular}{lccllcc}
\hline \multicolumn{2}{c}{ Mechanical properties } & \multicolumn{3}{c}{ Chemical analysis } \\
\multicolumn{1}{c}{ Values } & \multicolumn{2}{c}{ Parameters } & 2017-2018 & $\mathbf{2 0 1 8 - 2 0 1 9}$ \\
\hline Coarse sand & $\mathbf{2 0 1 7 - 2 0 1 8}$ & $\mathbf{2 0 1 8 - 2 0 1 9}$ & & $1.55 \%$ & $1.77 \%$ \\
Fine sand & $7.18 \%$ & $5.95 \%$ & Organic matter & $0.97 \%$ & $1.08 \%$ \\
Silt & $15.57 \%$ & $16.22 \%$ & $\mathbf{C a C O}_{3}$ & $0.96 \%$ & $0.92 \%$ \\
Clay & $23.66 \%$ & $25.09 \%$ & Available nitrogen & $0.55 \%$ & $0.62 \%$ \\
Textural class & $53.59 \%$ & $52.74 \%$ & Available phosphorus & $0.69 \%$ & $0.64 \%$ \\
& Clay loam & Clay loam & Available potassium & 7.55 & 7.74 \\
& & & pH & 0.84 & 0.93 \\
\hline
\end{tabular}




\section{Vegetative characteristics at the beginning of flowering:}

1. Plant height $(\mathrm{cm})$ : length of the main stem from soil surface to the plant apex using measuring tape.

2. Number of branches/plant.

3. Herb fresh weight (g)/plant.

4. Herb dry weight (g)/plant.

\section{Seeds yield parameters:}

After harvesting time, the plants were removed to station for sampling and other measurements the following measurements were taken:

1. Inflorescences weights (g)/plant.

2. Weight of 1000 seeds (g).

3. Seeds yield (g)/plant.

\section{Chemical constituents:}

1. Photosynthetic pigments: chlorophyll a, b and carotenoids were colorimetrically determined in leaves of chia according to the method described by Inskeep and Bloom (1985) and calculated as mg/g fresh weight.

2. Nitrogen, phosphorus, potassium and total carbohydrates: were determined in dried chia leaves according to the methods described by Horneck and Miller (1998), Hucker and Catroux (1980), Horneck and Hanson (1998) and Chaplin and Kennedy (1994), respectively.

3. Fixed oil productivity: the clean air dried seeds of chia were separately crushed in a Willey mill, then extracted in Soxhlet apparatus, samples of $10 \mathrm{~g}$ of seeds were moved into Soxhlet apparatus in $100 \mathrm{ml}$ of N-hexane and the extraction period extended to three hours (30-36 syphon cycle approx.). The N-hexane extract was dried over anhydrous sodium sulfate, then filtered and the oil was obtained by distillation under vacuum. The percent of fixed oil was calculated as weight/weight using the following equation
Fixed oil percentage $=$ Extracted fixed oil weight/seeds sample weight $\times 100$.

4. Fatty acids determination: the methyl esters of fatty acids were prepared by using benzene: methanol: concentrated sulfuric acid (10:86:4) and methylation was carried out for one hour at $80-90{ }^{\circ} \mathrm{C}$. The acidified solution was extracted three times with ether. The ether extract was washed by a distilled water (many times) till neutral condition was noticed with phenolphthalein indicator. The ether extract was dried over anhydrous sodium sulfate, filtered and finally evaporated under vacuum according to Stahl (1967). The residues represented the methylated fatty acids were analyzed by G.L.C. method.

\section{Statistical analysis:}

The means of all obtained data from the studied factors were subjected to analyses of variance (ANOVA) as factorial experiments in a complete randomized block design. The differences between the mean values of various treatments were compared by Duncan's multiple range test (Duncan, 1955) as given by Snedecor and Cochran (1989) using MSTAT-C statistical software package.

\section{RESULTS AND DISCUSSION}

\section{Effect of some safety growth stimulants treatments, zinc and their combination treatments on:}

\section{Vegetative growth measurements:}

Data presented in Tables (2 and 3) illustrate that, all safety growth stimulant treatments i.e. (chitosan, ascobien, humic and glutamic acids) succeeded in increasing all tested vegetative growth measurements (plant height, number of branches/plant, fresh and dry weights of chia (Salvia hispanica L.) plant, especially humic acid at $5 \mathrm{ml} / \mathrm{l}$ followed by glutamic acid at $200 \mathrm{ppm}$ in the first and second seasons. Irrespective control plants the lowest values of these parameters were scored by chitosan at $5 \mathrm{~g} / \mathrm{l}$ during $1^{\text {st }}$ and $2^{\text {nd }}$ seasons. 
Table 2. Effect of some safety growth stimulant treatments, zinc concentrations and their combination treatments on plant height and number of branches of chia (Salvia hispanica L.) plant, during 2018-2019 and 2019-2020 seasons.

\begin{tabular}{|c|c|c|c|c|c|c|c|c|}
\hline \multirow{3}{*}{$\begin{array}{l}\text { Safety growth stimulants } \\
\text { (A) }\end{array}$} & \multicolumn{8}{|c|}{ Zn concentration $(\mathrm{ppm})(\mathrm{B})$} \\
\hline & 0.0 & 100 & 200 & Mean & 0.0 & 100 & 200 & Mean \\
\hline & \multicolumn{4}{|c|}{ Plant height (cm) } & \multicolumn{4}{|c|}{ Number of branches/plant } \\
\hline & \multicolumn{8}{|c|}{$\mathbf{1}^{\text {st }}$ season } \\
\hline Control (tap water) & $93.96 \mathrm{j}$ & $98.30 \mathrm{i}$ & $99.29 \mathrm{i}$ & $97.18 \mathrm{e}$ & $16.67 \mathrm{i}$ & $19.67 \mathrm{~h}$ & $22.67 \mathrm{~g}$ & $19.67 \mathrm{e}$ \\
\hline Chitosan at $5 \mathrm{~g} / \mathrm{l}$ & $98.48 \mathrm{i}$ & $100.9 \mathrm{~h}$ & $102.7 \mathrm{~g}$ & $100.7 \mathrm{~d}$ & $19.33 \mathrm{~h}$ & $22.33 \mathrm{~g}$ & $23.67 \mathrm{~g}$ & $21.78 \mathrm{~d}$ \\
\hline Ascobien at 200 ppm & $100.8 \mathrm{~h}$ & $104.2 \mathrm{f}$ & $106.5 \mathrm{e}$ & $103.8 \mathrm{c}$ & $23.33 \mathrm{~g}$ & $25.33 \mathrm{f}$ & $27.33 \mathrm{e}$ & $25.33 \mathrm{c}$ \\
\hline Humic acid at $5 \mathrm{~m} / \mathrm{l}$ & 117.9 c & $120.2 \mathrm{~b}$ & $123.0 \mathrm{a}$ & $120.4 \mathrm{a}$ & $30.67 \mathrm{c}$ & $34.33 \mathrm{~b}$ & 35.67 a & $33.56 \mathrm{a}$ \\
\hline Glutamic acid at $200 \mathrm{ppm}$ & $104.4 \mathrm{f}$ & $107.3 \mathrm{e}$ & $110.5 \mathrm{~d}$ & $107.4 \mathrm{~b}$ & $29.33 \mathrm{~d}$ & 30.67 c & $31.67 \mathrm{c}$ & $30.56 \mathrm{~b}$ \\
\hline \multirow[t]{2}{*}{ Mean } & $103.1 \mathrm{c}$ & $106.2 \mathrm{~b}$ & $108.4 \mathrm{a}$ & & $23.87 \mathrm{c}$ & $26.47 \mathrm{~b}$ & $28.20 \mathrm{a}$ & \\
\hline & \multicolumn{8}{|c|}{$2^{\text {nd }}$ season } \\
\hline Control (tap water) & 94.561 & $97.79 \mathrm{k}$ & $100.3 \mathrm{j}$ & $97.55 \mathrm{e}$ & $17.67 \mathrm{i}$ & $20.00 \mathrm{~h}$ & $23.67 \mathrm{fg}$ & $20.44 \mathrm{e}$ \\
\hline Chitosan at $5 \mathrm{~g} / \mathrm{l}$ & $101.2 \mathrm{j}$ & $103.4 \mathrm{i}$ & $105.3 \mathrm{~h}$ & $103.3 \mathrm{~d}$ & $20.67 \mathrm{~h}$ & $22.67 \mathrm{~g}$ & $24.33 \mathrm{f}$ & $22.56 \mathrm{~d}$ \\
\hline Ascobien at 200 ppm & $103.2 \mathrm{i}$ & $106.1 \mathrm{gh}$ & $109.8 \mathrm{f}$ & $106.4 \mathrm{c}$ & $23.67 \mathrm{fg}$ & 26.67 e & $29.67 \mathrm{~d}$ & $26.67 \mathrm{c}$ \\
\hline Humic acid at $5 \mathrm{~m} / \mathrm{l}$ & $119.4 \mathrm{c}$ & $122.0 \mathrm{~b}$ & $124.2 \mathrm{a}$ & 121.9 a & $31.67 \mathrm{c}$ & $34.33 \mathrm{~b}$ & 36.67 a & $34.22 \mathrm{a}$ \\
\hline Glutamic acid at $200 \mathrm{ppm}$ & $106.9 \mathrm{~g}$ & $111.6 \mathrm{e}$ & $114.3 \mathrm{~d}$ & $110.9 \mathrm{~b}$ & 31.33 c & 31.67 c & $33.33 \mathrm{~b}$ & $32.11 \mathrm{~b}$ \\
\hline Mean & $105.1 \mathrm{c}$ & $108.2 \mathrm{~b}$ & 110.8 a & & $25.00 \mathrm{c}$ & $27.07 \mathrm{~b}$ & 29.53 a & \\
\hline
\end{tabular}

Table 3. Effect of some safety growth stimulant treatments, zinc concentrations and their combination treatments on herb fresh and dry weights (g)/plant of chia (Salvia hispanica L.) plant, during 2018-2019 and 2019-2020 seasons.

\begin{tabular}{|c|c|c|c|c|c|c|c|c|}
\hline \multirow{3}{*}{$\begin{array}{l}\text { Safety growth stimulants } \\
\text { (A) }\end{array}$} & \multicolumn{8}{|c|}{ Zn concentration $(\mathrm{ppm})(\mathrm{B})$} \\
\hline & 0.0 & 100 & 200 & Mean & 0.0 & 100 & 200 & Mean \\
\hline & \multicolumn{4}{|c|}{ Herb fresh weight (g)/plant } & \multicolumn{4}{|c|}{ Herb dry weight (g)/plant } \\
\hline & \multicolumn{8}{|c|}{$1^{\text {st }}$ season } \\
\hline Control (tap water) & 78.141 & $81.11 \mathrm{k}$ & $84.29 \mathrm{j}$ & 81.18 e & $11.25 \mathrm{l}$ & $12.92 \mathrm{k}$ & $13.62 \mathrm{jk}$ & $12.60 \mathrm{e}$ \\
\hline Chitosan at $5 \mathrm{~g} / \mathrm{l}$ & $82.22 \mathrm{k}$ & $87.48 \mathrm{i}$ & $92.75 \mathrm{~h}$ & $87.48 \mathrm{~d}$ & $14.26 \mathrm{j}$ & $16.08 \mathrm{i}$ & $18.26 \mathrm{~h}$ & $16.20 \mathrm{~d}$ \\
\hline Ascobien at 200 ppm & $120.4 \mathrm{~g}$ & $123.7 \mathrm{f}$ & $127.0 \mathrm{e}$ & $123.7 \mathrm{c}$ & $19.71 \mathrm{~g}$ & $21.37 \mathrm{f}$ & $23.15 \mathrm{e}$ & $21.41 \mathrm{c}$ \\
\hline Humic acid at $5 \mathrm{~m} / \mathrm{l}$ & $134.0 \mathrm{c}$ & $137.6 \mathrm{~b}$ & 141.6 a & 137.7 a & $25.33 \mathrm{c}$ & $27.34 \mathrm{ab}$ & $28.14 \mathrm{a}$ & $26.94 \mathrm{a}$ \\
\hline Glutamic acid at $200 \mathrm{ppm}$ & $130.5 \mathrm{~d}$ & $132.5 \mathrm{c}$ & $136.3 \mathrm{~b}$ & $133.1 \mathrm{~b}$ & 23.92 de & $24.83 \mathrm{~cd}$ & $26.96 \mathrm{~b}$ & $25.24 b$ \\
\hline \multirow[t]{2}{*}{ Mean } & $109.1 \mathrm{c}$ & $112.5 \mathrm{~b}$ & $116.4 \mathrm{a}$ & & 18.89 c & $20.51 \mathrm{~b}$ & $22.03 \mathrm{a}$ & \\
\hline & \multicolumn{8}{|c|}{$2^{\text {nd }}$ season } \\
\hline Control (tap water) & 80.141 & $84.09 \mathrm{k}$ & $89.52 \mathrm{j}$ & 84.58 e & $12.70 \mathrm{i}$ & $13.77 \mathrm{i}$ & $14.92 \mathrm{~h}$ & $13.80 \mathrm{e}$ \\
\hline Chitosan at $5 \mathrm{~g} / \mathrm{l}$ & $87.77 \mathrm{j}$ & $92.67 \mathrm{i}$ & $97.48 \mathrm{~h}$ & $92.64 \mathrm{~d}$ & $15.92 \mathrm{~h}$ & $17.55 \mathrm{~g}$ & $19.25 \mathrm{f}$ & $17.58 \mathrm{~d}$ \\
\hline Ascobien at $200 \mathrm{ppm}$ & $123.4 \mathrm{~g}$ & $130.1 \mathrm{f}$ & $132.0 \mathrm{e}$ & 128.5 c & $20.34 \mathrm{f}$ & $22.64 \mathrm{e}$ & $24.22 \mathrm{~d}$ & $22.40 \mathrm{c}$ \\
\hline Humic acid at $5 \mathrm{~m} / \mathrm{l}$ & $139.3 \mathrm{c}$ & $142.4 \mathrm{~b}$ & $147.0 \mathrm{a}$ & 142.9 a & $25.74 \mathrm{c}$ & $27.92 \mathrm{~b}$ & $29.75 \mathrm{a}$ & $27.80 \mathrm{a}$ \\
\hline Glutamic acid at $200 \mathrm{ppm}$ & $132.6 \mathrm{e}$ & $135.4 \mathrm{~d}$ & $137.7 \mathrm{c}$ & $135.3 \mathrm{~b}$ & $24.66 \mathrm{~cd}$ & $25.61 \mathrm{c}$ & $27.76 \mathrm{~b}$ & $26.01 \mathrm{~b}$ \\
\hline Mean & $112.7 \mathrm{c}$ & $116.9 \mathrm{~b}$ & $120.8 \mathrm{a}$ & & 19.87 c & $21.50 \mathrm{~b}$ & $23.18 \mathrm{a}$ & \\
\hline
\end{tabular}


As for zinc concentration treatments, data presented in the same Tables illustrated that there was a positive relationship between the values of abovementioned parameters and zinc concentration, hence as the concentration of zinc increased the values of plant height, number of branches/plant, fresh and dry weights increased till reach the highest increases at the highest concentration (200 ppm) during the first and second seasons. Regarding the interaction effect between safety growth stimulant treatments and zinc concentrations data presented in Tables (2 and 3) show that all combinations treatments increased the plant height, number of branches/plant, fresh and dry weights of chia (Salvia hispanica L.) plant with significant differences as compared with control plants in the two seasons of this study. However, the combination of humic acid at $5 \mathrm{ml} / \mathrm{l}$ showed to be the most effective ones for inducing the highest values of these parameters particularly those sprayed with the highest concentration of zinc (200 ppm), followed descending by the interaction treatments of humic acid at $5 \mathrm{ml} / \mathrm{l}$ with the medium concentration of zinc (100 ppm) or the combination of glutamic acid at $200 \mathrm{ppm}$ with the concentration of zinc (200 ppm) with non-significant differences among themselves in most cases in the two seasons. Moreover, the combination of glutamic acid at $100 \mathrm{ppm}$ with the concentration of zinc (100 ppm) or the combination of ascobien at 200 ppm with the concentration of zinc (200 ppm) resulted in highly increments in this concern in both seasons. Irrespective of control, the lowest values of these parameters were gained by chitosan at $5 \mathrm{~g} / \mathrm{l}$ combinations, especially those received no zinc sprays in the two seasons.

The aforementioned results of safety growth stimulants concerning vegetative growth are in parallel with those obtained by Aiyafar et al. (2015) on Nigella sativa L., ElShayeb et al. (2015) on Salvia officinalis L., Hendawy et al. (2015) on Mentha piperita var. citrata, Nasiri et al. (2015) on Pelargonium graveolens, Awad (2016) on
Carum carvi and El-Khateeb et al. (2017) on Majorana hortensis. Ibrahim and Helaly (2017) illustrated that, the better growth parameters, higher yield components, fixed oil production, chemical constituents of seeds and as well as trigonelline content in seeds could be obtained by spraying humic acid at 2 l/feddan on fertilized fenugreek plants.

The results of amino acids are in agreement with those of Haj Seyed Hadi et al. (2011) on chamomile plant, Datir et al. (2012) on Capsicum annum L., Hussein (2013) on chamomile plant, Rahimi et al. (2013) on basil, Omer et al. (2013) on chamomile, Mohamed et al. (2016) on Ocimum basilicum L. cV. Genoveseand, Mahdy et al. (2019) on roselle plant. Meanwhile, Orlita et al. (2008) on Ruta graveolens, Yin et al. (2012) on Majorana vulgare, El-Bassiony et al. (2014) on fennel, Mehregan et al. (2017) on Stevia rebaudiana, El-Khateeb et al. (2017) on Majorana hortensis and Afifi et al. (2018) on snap bean.

On the other hand, the abovementioned results of zinc are nearly similar to those obtained by Yadegari (2015) on borago, thyme and marigold and Abou-Shleell (2017) on Moringa oleifera. Ghatas and Mohamed (2018) on Cymbopgon citratuts and Adib et al. (2020) on cumin (Cuminum cyminum L.) declared that foliar application of $\mathrm{Zn}$ improve the injurious effects of water deficiency through alteration in vegetative growth. In this concern, the role of humic acid on growth and development of the plants is one of the natural growths bio stimulants as it is considered an important component of organic substances in aquatic systems. Humic acid has a great importance for the plant in terms of its effect on growth in addition to its clear importance to the soil as it works to improve the properties of the soil and increase the rate of microbial activity as it enhances the absorption of many nutrients as a chelating agent. On the other hand, HA activates microorganisms in the soil and works to increase humic and 


\section{Y.F.Y. Mohamed and Y.A.A. Ghatas}

organic matter, especially in alkaline soils containing little of the organic matter. It is known that humic materials increase the activity of root growth such as auxins, which in turn is reflected in the increased growth of the plant in various stages of growth, and leaf pigments (Berlyn and Russo, 1990; Frankenberger and Arshad, 1995; Graves et al., 2004; Pereira1 et al., 2019). Glutamic acid is important metabolic cycles of the plant, the carbon and nitrogen cycles and has an influence on sugars and protein. The glutamic acid is an important for the synthesis of the auxin and fruit set (Taiz and Zeiger, 2002). Amino acids contribute to the tolerance of plants against biotic and abiotic stresses either directly or indirectly by serving as precursors to secondary compounds and hormones. Glutamic acid also functions in the synthesis of other organic compounds, such as protein, amines, purines and pyrimidines, alkaloids, vitamins, enzymes, terpenoids and others. Amino acids are critical to life, and have many functions in metabolism (Behzad, 2011).

The importance of Ascobien comes in that it contains ascorbic, citric acids, where the ascorbic and citric acid play an important role in physiological processes such as regulating growth and metabolism of the plants. Noctor and Foyer (1998) and Smirnoff (2005) showed that ascorbic acid acts as a primary substrate in the cyclical pathway for detoxification and neutralization of superoxide radicals and singlet oxygen. Also, it is a small, water-soluble molecule. In this context, Abdossi and Danaee (2019) suggested that, using ascorbic and citric acids application maximized cell division, growth and preservation of cell. However, the effect on the regulation of growth and physiological processes within the plant, which in turn is reflected in the increase of vegetative, flowering growth and chemical components on carnation plant.

Additionally, Gornik et al. (2008) illustrated that, chitosan increased enzymes activities of nitrogen metabolism (nitrate reductase, glutamine synthetase and protease) and improved the transportation of nitrogen. The promotive effect of chitosan on growth parameter may be due to its effect on increasing nutrient uptake and availability, chlorophyll contents and photosynthetic rate through adjusting cell osmotic pressure and increasing enzyme activities (Hadwiger, 2013; Malekpoor et al., 2016 and Salachna et al., 2017).

Moreover, Zinc is one of the essential microelements for growth and flowering of plants (Chandler, 1982). Zinc is an important micronutrient its closely involved the metabolism of RNA and ribosomal content in plant cells, leading to stimulation carbohydrates, proteins and the DNA formation. It is also required for the synthesis of tryptophan, is a precursor of IAA which acts as a growth promoting substance. Also, Zinc has three functions: catalytic, cocatalytic (coactive) and structural (Amberger, 1974). Therefore, sufficient amount of these nutrients in the plant is necessary for normal growth, in order to obtain satisfactory yield (Yassen et al., 2010).

\section{Yield parameters:}

Data presented in Tables (4 and 5) reveal that the heaviest inflorescence weights/plant (g), weight of 1000 seeds/g and weight of seeds/plant (g) were scored by humic acid at $5 \mathrm{ml} / \mathrm{l}$ followed by glutamic acid at $200 \mathrm{ppm}$ in the first and second seasons. Also, the aforementioned yield parameters were greatly affected by spraying chia plants with zinc treatments, particularly the highest concentration (200 ppm) as compared with unsprayed plants in the two seasons. As for the interaction effect between all safety growth stimulants treatments and zinc treatments, data in Tables (4 and 5) demonstrated that all resulted combinations increased aforementioned parameters in the two seasons. However, the highest values were recorded by the combined treatments between humic acid at $5 \mathrm{ml} / \mathrm{l}$ with zinc at 200 ppm followed descendingly by humic aci at $5 \mathrm{~m} / \mathrm{l}$ and spray the plant of zinc at 100 ppm in the first and second seasons. 
Table 4. Effect of some safety growth stimulant treatments, zinc concentrations and their combination treatments on inflorescence weights and weight of 1000 seeds (g)/plant of chia (Salvia hispanica L.) plant, during 2018-2019 and 2019-2020 seasons.

\begin{tabular}{|c|c|c|c|c|c|c|c|c|}
\hline \multirow{3}{*}{$\begin{array}{l}\text { Safety growth stimulants } \\
\text { (A) }\end{array}$} & \multicolumn{8}{|c|}{ Zn concentration (ppm) (B) } \\
\hline & 0.0 & 100 & 200 & Mean & 0.0 & 100 & 200 & Mean \\
\hline & \multicolumn{4}{|c|}{ Inflorescences weights (g)/plant } & \multicolumn{4}{|c|}{ Weight of 1000 seeds (g) } \\
\hline & \multicolumn{8}{|c|}{$1^{\text {st }}$ season } \\
\hline Control (tap water) & $7.60 \mathrm{~g}$ & $8.07 \mathrm{fg}$ & $8.44 \mathrm{f}$ & $8.04 \mathrm{e}$ & 1.08 о & $1.18 \mathrm{~m}$ & 1.221 & $1.16 \mathrm{e}$ \\
\hline Chitosan at $5 \mathrm{~g} / \mathrm{l}$ & $8.10 \mathrm{fg}$ & $9.96 \mathrm{e}$ & $11.36 \mathrm{~d}$ & $9.81 \mathrm{~d}$ & $1.18 \mathrm{n}$ & $1.24 \mathrm{k}$ & $1.27 \mathrm{i}$ & $1.23 \mathrm{~d}$ \\
\hline Ascobien at $200 \mathrm{ppm}$ & $9.82 \mathrm{e}$ & $11.30 \mathrm{~d}$ & 12.19 c & $11.10 \mathrm{c}$ & $1.26 \mathrm{j}$ & $1.29 \mathrm{~h}$ & $1.32 \mathrm{f}$ & $1.29 \mathrm{c}$ \\
\hline Humic acid at $5 \mathrm{~m} / \mathrm{l}$ & $12.81 \mathrm{bc}$ & $13.33 \mathrm{~b}$ & $15.11 \mathrm{a}$ & 13.75 a & $1.37 \mathrm{~d}$ & $1.42 \mathrm{~b}$ & $1.45 \mathrm{a}$ & $1.41 \mathrm{a}$ \\
\hline Glutamic acid at $200 \mathrm{ppm}$ & $11.03 \mathrm{~d}$ & $12.14 \mathrm{c}$ & $13.40 \mathrm{~b}$ & $12.19 \mathrm{~b}$ & $1.30 \mathrm{~g}$ & $1.34 \mathrm{e}$ & $1.38 \mathrm{c}$ & $1.34 \mathrm{~b}$ \\
\hline \multirow[t]{2}{*}{ Mean } & $9.87 \mathrm{c}$ & $10.96 \mathrm{~b}$ & $12.10 \mathrm{a}$ & & $1.23 \mathrm{c}$ & $1.29 \mathrm{~b}$ & $1.33 \mathrm{a}$ & \\
\hline & \multicolumn{8}{|c|}{$2^{\text {nd }}$ season } \\
\hline Control (tap water) & $8.12 \mathrm{~g}$ & $8.85 \mathrm{fg}$ & $9.26 \mathrm{f}$ & 8.75 e & $1.11 \mathrm{n}$ & $1.17 \mathrm{~m}$ & $1.22 \mathrm{k}$ & $1.17 \mathrm{e}$ \\
\hline Chitosan at $5 \mathrm{~g} / \mathrm{l}$ & $9.27 \mathrm{f}$ & $12.06 \mathrm{~cd}$ & $12.17 \mathrm{~cd}$ & $11.17 \mathrm{~d}$ & $1.20 \mathrm{l}$ & $1.25 \mathrm{j}$ & $1.30 \mathrm{~h}$ & $1.25 \mathrm{~d}$ \\
\hline Ascobien at $200 \mathrm{ppm}$ & 10.89 e & 11.91 de & 13.13 bc & $11.98 \mathrm{c}$ & $1.27 \mathrm{i}$ & $1.30 \mathrm{~h}$ & $1.32 \mathrm{f}$ & $1.30 \mathrm{c}$ \\
\hline Humic acid at $5 \mathrm{~m} / \mathrm{l}$ & $13.71 \mathrm{~b}$ & $14.11 \mathrm{~b}$ & 15.33 a & 14.38 a & $11.37 \mathrm{~d}$ & $1.42 \mathrm{~b}$ & $1.47 \mathrm{a}$ & $1.42 \mathrm{a}$ \\
\hline Glutamic acid at $200 \mathrm{ppm}$ & 11.90 de & $12.61 \mathrm{~cd}$ & $13.85 \mathrm{~b}$ & $12.79 \mathrm{~b}$ & $1.31 \mathrm{~g}$ & $1.35 \mathrm{e}$ & $1.39 \mathrm{c}$ & $1.35 \mathrm{~b}$ \\
\hline Mean & 10.78 c & $11.91 \mathrm{~b}$ & 12.75 a & & $1.25 \mathrm{c}$ & $1.30 \mathrm{~b}$ & $1.34 \mathrm{a}$ & \\
\hline
\end{tabular}

Table 5. Effect of some safety growth stimulant treatments, zinc concentrations and their combination treatments on seeds weight (g)/plant and chlorophyll a $(\mathrm{mg} / \mathrm{g}$ fresh weight) of chia (Salvia hispanica L.) plant, during 2018-2019 and 20192020 seasons.

\begin{tabular}{|c|c|c|c|c|c|c|c|c|}
\hline \multirow{3}{*}{$\begin{array}{l}\text { Safety growth stimulants } \\
\text { (A) }\end{array}$} & \multicolumn{8}{|c|}{ Zn concentration $(\mathrm{ppm})(\mathrm{B})$} \\
\hline & 0.0 & 100 & 200 & Mean & $\mathbf{0 . 0}$ & 100 & 200 & Mean \\
\hline & \multicolumn{4}{|c|}{ Seeds weight (g)/plant } & \multicolumn{4}{|c|}{ Chlorophyll a (mg/g fresh weight) } \\
\hline & \multicolumn{8}{|c|}{$\mathbf{1}^{\text {st }}$ season } \\
\hline Control (tap water) & $3.10 \mathrm{~h}$ & $3.75 \mathrm{~g}$ & $3.96 \mathrm{~g}$ & $3.60 \mathrm{e}$ & 0.7981 & $0.812 \mathrm{k}$ & $0.828 \mathrm{j}$ & $0.813 \mathrm{e}$ \\
\hline Chitosan at $5 \mathrm{~g} / \mathrm{l}$ & $4.81 \mathrm{f}$ & $5.92 \mathrm{e}$ & $6.85 \mathrm{~d}$ & $5.86 \mathrm{~d}$ & $0.931 \mathrm{i}$ & $0.944 \mathrm{~h}$ & $0.951 \mathrm{~g}$ & $0.942 \mathrm{~d}$ \\
\hline Ascobien at $200 \mathrm{ppm}$ & $6.10 \mathrm{e}$ & $6.88 \mathrm{~d}$ & $7.12 \mathrm{~cd}$ & $6.70 \mathrm{c}$ & $0.992 \mathrm{f}$ & $0.995 \mathrm{f}$ & $1.10 \mathrm{e}$ & $1.03 \mathrm{c}$ \\
\hline Humic acid at $5 \mathrm{~m} / \mathrm{l}$ & $7.56 \mathrm{c}$ & $8.20 \mathrm{~b}$ & $9.23 \mathrm{a}$ & 8.33 a & $1.11 \mathrm{~d}$ & $1.13 \mathrm{~b}$ & $1.14 \mathrm{a}$ & $1.13 \mathrm{a}$ \\
\hline Glutamic acid at $200 \mathrm{ppm}$ & $6.93 \mathrm{~d}$ & $7.27 \mathrm{~cd}$ & $8.21 \mathrm{~b}$ & $7.47 \mathrm{~b}$ & $1.11 \mathrm{e}$ & $1.11 \mathrm{~d}$ & 1.12 c & $1.11 \mathrm{~b}$ \\
\hline \multirow[t]{2}{*}{ Mean } & $5.70 \mathrm{c}$ & $6.40 \mathrm{~b}$ & $7.08 \mathrm{a}$ & & 0.989 c & $0.999 \mathrm{~b}$ & $1.03 \mathrm{a}$ & \\
\hline & \multicolumn{8}{|c|}{$2^{\text {nd }}$ season } \\
\hline Control (tap water) & $3.53 \mathrm{i}$ & $3.73 \mathrm{i}$ & $4.51 \mathrm{~h}$ & $3.92 \mathrm{e}$ & $0.812 \mathrm{~m}$ & $0.820 \mathrm{l}$ & $0.834 \mathrm{k}$ & $0.822 \mathrm{e}$ \\
\hline Chitosan at $5 \mathrm{~g} / \mathrm{l}$ & $5.26 \mathrm{~g}$ & $6.11 \mathrm{f}$ & 7.24 de & $6.20 \mathrm{~d}$ & $0.939 \mathrm{j}$ & $0.943 \mathrm{j}$ & $0.951 \mathrm{i}$ & $0.944 \mathrm{~d}$ \\
\hline Ascobien at $200 \mathrm{ppm}$ & $6.62 \mathrm{ef}$ & 6.60 ef & $6.86 \mathrm{~d}-\mathrm{f}$ & $6.96 \mathrm{c}$ & $0.990 \mathrm{~h}$ & $1.00 \mathrm{~g}$ & $1.10 \mathrm{f}$ & $1.03 \mathrm{c}$ \\
\hline Humic acid at $5 \mathrm{~m} / \mathrm{l}$ & 7.30 de & $8.55 b$ & 9.47 a & $8.44 \mathrm{a}$ & $1.12 \mathrm{~d}$ & $1.13 \mathrm{~b}$ & $1.14 \mathrm{a}$ & $1.13 \mathrm{a}$ \\
\hline Glutamic acid at $200 \mathrm{ppm}$ & $9.93 \mathrm{~d}-\mathrm{f}$ & $7.66 \mathrm{~cd}$ & $8.37 \mathrm{bc}$ & $7.65 \mathrm{~b}$ & $1.11 \mathrm{e}$ & $1.12 \mathrm{~cd}$ & $1.12 \mathrm{c}$ & $1.11 \mathrm{~b}$ \\
\hline Mean & $5.93 \mathrm{c}$ & $6.53 \mathrm{~b}$ & 7.29 a & & 0.994 c & $1.00 \mathrm{~b}$ & $1.03 \mathrm{a}$ & \\
\hline
\end{tabular}


Additionally, the third values in this respect scored by glutamic acid at $200 \mathrm{ppm}$ combined with zinc at $200 \mathrm{ppm}$ in both seasons. The lowest values of these parameters were gained by combination treatment between control (tap water) with $0.0 \mathrm{ppm}$ zinc sprays in the two seasons.

The results of safety growth stimulants i.e. (humic acid, amino acids, ascobien and chitosan) concerning yield parameters are in parallel with those obtained, Aiyafar et al. (2015) on Nigella sativa L., Akbari and Gholam (2016) on fennel, Ariafar and Forouzandeh (2017) on black cumin. Ibrahim and Helaly (2017) illustrated that, the better, higher yield components, fixed oil production, chemical constituents of seeds and as well as trigonelline content in seeds could be obtained by spraying humic acid at 2 l/feddan level on fertilized fenugreek plants with NK at $75 \%$ of recommended rate. The aforementioned results of amino acids are in agreement those of Datir et al. (2012) on Capsicum annum L., Hussein (2013) on chamomile, Omer et al. (2013) on chamomile, Maryam et al. (2014), Mohamed et al. (2015) on Ocimum basilicum, L. cV. Genovese and Mohamed et al. (2016) on Ocimum basilicum L. cv. Genovese. Mahdy et al. (2019) on roselle plant declared that, The high values of growth components (plant height, number of branches, dry weight of leaves and leaf area) and yield parameters (seed yield, seed yield per plant, fixed oil per plant and fixed oil yield) could be obtained under high level of amino acid (1000 ppm).

Additionally, Orlita, et al. (2008) on Ruta graveolens, Yin et al. (2012) on Majorana vulgare, El-Bassiony et al. ( 2014) on fennel and Mehregan et al. (2017) on Stevia rebaudiana and El-Khateeb et al. (2017) on Majorana hortensis. Afifi et al. (2018) concluded that chitosan at the rate of 200 ppm gave high growth, yield and its components as well as quality of snap bean. The abovementioned results of micronutrients are nearly similar to those obtained by Saeid Zehtab et al. (2012) on Psyllium plant. Adib et al. (2020) on cumin (Cuminum cyminum L.) demonstrated that foliar application of $\mathrm{Zn}$ improves the injurious effects of water deficiency on plant through alteration in yield characteristics.

\section{Chemical composition:}

\section{Chlorophyll a, b and carotenoids contents (mg/g f.w):}

Data presented in Tables (5 and 6) clear that there were highly significant differences in leaf chlorophyll a, b and carotenoids content as response to the studied safety growth stimulants treatments i.e. (chitosan, ascobien, humic and glutamic acids when compared with control in both seasons. Meanwhile, the highest values of these parameters were scored by humic acid, followed glutamic acid in both seasons. With respect for the effect of zinc concentration treatments, data in Tables (6 and 7) declare that all concentration of zinc concentration treatments (100 and $200 \mathrm{ppm}$ ) resulted in highly significant increments in this parameter, with superiority for the highest concentration in both seasons. As for the interaction effect between growth stimulants treatments with zinc concentration treatments, data in the same Tables illustrated that the highest values of abovementioned parameters were recorded by humic acid combined zinc concentration at $200 \mathrm{ppm}$, followed by the combined treatment between humic acid combined zinc concentration at $100 \mathrm{ppm}$ in the first and second seasons. The third value in this concern by using the combined treatment of glutamic acid and zinc at 200 ppm in both seasons. Irrespective control, the lowest values of these parameters were gained by chitosan at $5 \mathrm{~g} / \mathrm{l}$ combinations, especially those received no zinc sprays in the two seasons.

\section{Nitrogen, phosphorus, potassium and total carbohydrates contents:}

Data presented in Tables (7 and 8) demonstrate that all applied safety growth stimulant treatments significantly succeeded in increasing the values of $\mathrm{N}, \mathrm{P}, \mathrm{K}$ and total 
Table 6. Effect of some safety growth stimulant treatments, zinc concentrations and their combination treatments on chlorophyll $b$ and carotenoids (mg/g fresh weight) of chia (Salvia hispanica L.) plant, during 2018-2019 and 2019-2020 seasons.

Zn concentration (ppm) (B)

\begin{tabular}{|c|c|c|c|c|c|c|c|c|}
\hline \multirow[t]{2}{*}{$\begin{array}{l}\text { Safety growth stimulants } \\
\text { (A) }\end{array}$} & $\mathbf{0 . 0}$ & 100 & 200 & Mean & 0.0 & 100 & 200 & Mean \\
\hline & \multicolumn{4}{|c|}{ Chlorophyll b (mg/g fresh weight) } & \multicolumn{4}{|c|}{ Carotenoids (mg/g fresh weight) } \\
\hline & \multicolumn{8}{|c|}{$1^{\text {st }}$ season } \\
\hline Control (tap water) & $0.371 \mathrm{n}$ & $0.378 \mathrm{~m}$ & $0.389 \mathrm{l}$ & $0.380 \mathrm{e}$ & $0.188 \mathrm{~m}$ & 0.1981 & $0.209 \mathrm{k}$ & $0.198 \mathrm{e}$ \\
\hline Chitosan at $5 \mathrm{~g} / \mathbf{l}$ & $0.412 \mathrm{k}$ & $0.421 \mathrm{j}$ & $0.432 \mathrm{i}$ & $0.422 \mathrm{~d}$ & $0.250 \mathrm{j}$ & $0.260 \mathrm{i}$ & $0.271 \mathrm{~g}$ & $0.260 \mathrm{~d}$ \\
\hline Ascobien at 200 ppm & $0.489 \mathrm{~h}$ & $0.512 \mathrm{~g}$ & $0.520 \mathrm{f}$ & 0.507 c & $0.266 \mathrm{~h}$ & $0.272 \mathrm{~g}$ & $0.281 \mathrm{f}$ & $0.273 \mathrm{c}$ \\
\hline Humic acid at $5 \mathrm{~m} / \mathrm{l}$ & 0.581 c & $0.591 \mathrm{~b}$ & 0.612 a & 0.595 a & 0.310 c & $0.327 \mathrm{~b}$ & $0.336 \mathrm{a}$ & $0.325 \mathrm{a}$ \\
\hline Glutamic acid at $200 \mathrm{ppm}$ & $0.531 \mathrm{e}$ & $0.540 \mathrm{~d}$ & 0.533 e & $0.535 \mathrm{~b}$ & 0.292 e & $0.300 \mathrm{~d}$ & 0.307 c & $0.299 \mathrm{~b}$ \\
\hline \multirow[t]{2}{*}{ Mean } & $0.477 \mathrm{c}$ & $0.488 \mathrm{~b}$ & $0.497 \mathrm{a}$ & & $0.261 \mathrm{c}$ & $0.272 \mathrm{~b}$ & $0.281 \mathrm{a}$ & \\
\hline & \multicolumn{8}{|c|}{$2^{\text {nd }}$ season } \\
\hline Control (tap water) & $0.379 \mathrm{n}$ & $0.385 \mathrm{~m}$ & 0.3931 & $0.386 \mathrm{e}$ & $0.192 \mathrm{~m}$ & 0.2041 & $0.216 \mathrm{k}$ & $0.204 \mathrm{e}$ \\
\hline Chitosan at $5 \mathrm{~g} / \mathrm{l}$ & $0.423 \mathrm{k}$ & $0.430 \mathrm{j}$ & $0.437 \mathrm{i}$ & $0.430 \mathrm{~d}$ & $0.253 \mathrm{j}$ & $0.268 \mathrm{i}$ & $0.278 \mathrm{~h}$ & $0.266 \mathrm{~d}$ \\
\hline Ascobien at 200 ppm & $0.501 \mathrm{~h}$ & $0.520 \mathrm{~g}$ & $0.528 \mathrm{f}$ & $0.516 \mathrm{c}$ & $0.270 \mathrm{i}$ & $0.276 \mathrm{~h}$ & $0.286 \mathrm{~g}$ & $0.277 \mathrm{c}$ \\
\hline Humic acid at $5 \mathrm{~m} / \mathrm{l}$ & $0.589 \mathrm{~b}$ & $0.593 \mathrm{~b}$ & 0.618 a & $0.600 \mathrm{a}$ & 0.316 c & $0.331 \mathrm{~b}$ & 0.340 a & 0.329 a \\
\hline Glutamic acid at $200 \mathrm{ppm}$ & $0.534 \mathrm{e}$ & $0.543 \mathrm{~d}$ & $0.560 \mathrm{c}$ & $0.546 \mathrm{~b}$ & $0.293 \mathrm{f}$ & 0.300 e & $0.311 \mathrm{~d}$ & $0.302 \mathrm{~b}$ \\
\hline Mean & $0.485 \mathrm{c}$ & $0.494 \mathrm{~b}$ & $0.507 \mathrm{a}$ & & 0.265 c & $0.276 \mathrm{~b}$ & $0.286 \mathrm{a}$ & \\
\hline
\end{tabular}

Table 7. Effect of some safety growth stimulant treatments, zinc concentrations and their combination treatments on $\mathrm{N} \%$ and $\mathrm{P} \%$ of chia (Salvia hispanica L.) plant, during 2018-2019 and 2019-2020 seasons.

\begin{tabular}{|c|c|c|c|c|c|c|c|c|}
\hline \multirow{3}{*}{$\begin{array}{l}\text { Safety growth stimulants } \\
\text { (A) }\end{array}$} & \multicolumn{8}{|c|}{ Zn concentration (ppm) (B) } \\
\hline & 0.0 & 100 & 200 & Mean & 0.0 & 100 & 200 & Mean \\
\hline & \multicolumn{4}{|c|}{ N\% } & \multicolumn{4}{|c|}{$\mathbf{P} \%$} \\
\hline & \multicolumn{8}{|c|}{$1^{\text {st }}$ season } \\
\hline Control (tap water) & $1.97 \mathrm{k}$ & $2.05 \mathrm{j}$ & $2.13 \mathrm{i}$ & $2.05 \mathrm{e}$ & $0.203 \mathrm{l}$ & $0.214 \mathrm{k}$ & $0.218 \mathrm{j}$ & $0.211 \mathrm{~d}$ \\
\hline Chitosan at $5 \mathrm{~g} / \mathrm{l}$ & $2.40 \mathrm{~h}$ & $2.50 \mathrm{~g}$ & $2.61 \mathrm{f}$ & $2.50 \mathrm{~d}$ & $0.260 \mathrm{i}$ & $0.276 \mathrm{~g}$ & $0.282 \mathrm{f}$ & $0.273 \mathrm{c}$ \\
\hline Ascobien at $200 \mathrm{ppm}$ & $2.66 \mathrm{f}$ & $2.79 \mathrm{e}$ & $2.90 \mathrm{~d}$ & $2.78 \mathrm{c}$ & $0.261 \mathrm{i}$ & $0.272 \mathrm{~h}$ & $0.281 \mathrm{f}$ & $0.271 \mathrm{c}$ \\
\hline Humic acid at $5 \mathrm{~m} / \mathrm{l}$ & $3.00 \mathrm{c}$ & $3.16 \mathrm{~b}$ & $3.40 \mathrm{a}$ & 3.19 a & $0.288 \mathrm{e}$ & $0.312 \mathrm{~b}$ & 0.317 a & $0.306 \mathrm{a}$ \\
\hline Glutamic acid at $200 \mathrm{ppm}$ & $2.83 \mathrm{e}$ & $2.92 \mathrm{~d}$ & $3.04 \mathrm{c}$ & $2.93 \mathrm{~b}$ & $0.269 \mathrm{~h}$ & $0.294 \mathrm{~d}$ & 0.303 c & $0.289 \mathrm{~b}$ \\
\hline \multirow[t]{2}{*}{ Mean } & $2.57 \mathrm{c}$ & $2.69 \mathrm{~b}$ & $2.82 \mathrm{a}$ & & $0.256 \mathrm{c}$ & $0.274 \mathrm{~b}$ & $0.281 \mathrm{a}$ & \\
\hline & \multicolumn{8}{|c|}{$2^{\text {nd }}$ season } \\
\hline Control (tap water) & $2.07 \mathrm{l}$ & $2.14 \mathrm{k}$ & $2.20 \mathrm{j}$ & $2.14 \mathrm{e}$ & $0.199 \mathrm{l}$ & $0.210 \mathrm{k}$ & $0.215 \mathrm{j}$ & $0.208 \mathrm{~d}$ \\
\hline Chitosan at $5 \mathrm{~g} / \mathrm{l}$ & $2.44 \mathrm{i}$ & $2.56 \mathrm{~h}$ & $2.65 \mathrm{~g}$ & $2.55 \mathrm{~d}$ & $0.258 \mathrm{i}$ & $0.281 \mathrm{~g}$ & $0.290 \mathrm{ef}$ & $0.276 \mathrm{c}$ \\
\hline Ascobien at 200 ppm & $2.70 \mathrm{f}$ & $2.85 \mathrm{e}$ & $2.94 \mathrm{~d}$ & $2.83 \mathrm{c}$ & $0.263 \mathrm{~h}$ & $0.279 \mathrm{~g}$ & $0.281 \mathrm{~g}$ & $0.274 \mathrm{c}$ \\
\hline Humic acid at $5 \mathrm{~m} / \mathrm{l}$ & $3.05 \mathrm{c}$ & $3.13 \mathrm{~b}$ & $3.41 \mathrm{a}$ & $3.20 \mathrm{a}$ & $0.294 \mathrm{~d}$ & $0.311 \mathrm{~b}$ & $0.320 \mathrm{a}$ & $0.308 \mathrm{a}$ \\
\hline Glutamic acid at $200 \mathrm{ppm}$ & 2.90 de & $3.02 \mathrm{c}$ & $3.17 \mathrm{~b}$ & $3.02 \mathrm{~b}$ & $0.288 \mathrm{f}$ & 0.294 de & 0.303 c & $0.295 \mathrm{~b}$ \\
\hline Mean & $2.63 \mathrm{c}$ & $2.74 \mathrm{~b}$ & $2.87 \mathrm{a}$ & & $0.261 \mathrm{c}$ & $0.275 \mathrm{~b}$ & $0.282 \mathrm{a}$ & \\
\hline
\end{tabular}


Table 8. Effect of some safety growth stimulant treatments, zinc concentrations and their combination treatments on $\mathrm{K} \%$ and total carbohydrates \% of chia (Salvia hispanica L.) plant, during 2018-2019 and 2019-2020 seasons.

\begin{tabular}{|c|c|c|c|c|c|c|c|c|}
\hline \multirow{3}{*}{$\begin{array}{l}\text { Safety growth stimulants } \\
\text { (A) }\end{array}$} & \multicolumn{8}{|c|}{ Zn concentration $(\mathrm{ppm})(\mathrm{B})$} \\
\hline & 0.0 & 100 & 200 & Mean & 0.0 & 100 & 200 & Mean \\
\hline & \multicolumn{4}{|c|}{ K\% } & \multicolumn{4}{|c|}{ Total carbohydrates (\%) } \\
\hline & \multicolumn{8}{|c|}{$1^{\text {st }}$ season } \\
\hline Control (tap water) & $1.45 \mathrm{i}$ & $1.53 \mathrm{hi}$ & $1.67 \mathrm{gh}$ & $1.55 \mathrm{e}$ & $12.95 \mathrm{k}$ & $13.28 \mathrm{jk}$ & $13.66 \mathrm{j}$ & 13.29 e \\
\hline Chitosan at $5 \mathrm{~g} / \mathrm{l}$ & $1.80 \mathrm{fg}$ & $1.94 \mathrm{ef}$ & $2.05 \mathrm{de}$ & $1.93 \mathrm{c}$ & $13.36 \mathrm{jk}$ & $15.13 \mathrm{i}$ & $16.62 \mathrm{~g}$ & $15.04 \mathrm{~d}$ \\
\hline Ascobien at $200 \mathrm{ppm}$ & $1.57 \mathrm{hi}$ & $1.92 \mathrm{ef}$ & $1.97 \mathrm{de}$ & $1.82 \mathrm{~d}$ & $15.67 \mathrm{hi}$ & 17.40 ef & $17.96 \mathrm{de}$ & $17.01 \mathrm{c}$ \\
\hline Humic acid at $5 \mathrm{~m} / \mathrm{l}$ & $2.10 \mathrm{~cd}$ & $2.32 \mathrm{ab}$ & $2.42 \mathrm{a}$ & $2.28 \mathrm{a}$ & $17.29 \mathrm{f}$ & $19.99 \mathrm{~b}$ & 21.77 a & $19.68 \mathrm{a}$ \\
\hline Glutamic acid at $200 \mathrm{ppm}$ & $1.90 \mathrm{ef}$ & $2.10 \mathrm{~cd}$ & $2.24 \mathrm{bc}$ & $2.08 \mathrm{~b}$ & $16.00 \mathrm{~h}$ & $18.43 \mathrm{~cd}$ & $18.88 \mathrm{c}$ & $17.77 \mathrm{~b}$ \\
\hline \multirow[t]{2}{*}{ Mean } & $1.76 \mathrm{c}$ & $1.96 \mathrm{~b}$ & $2.07 \mathrm{a}$ & & $15.05 \mathrm{c}$ & $16.85 \mathrm{~b}$ & $17.78 \mathrm{a}$ & \\
\hline & \multicolumn{8}{|c|}{$2^{\text {nd }}$ season } \\
\hline Control (tap water) & $1.50 \mathrm{n}$ & $1.57 \mathrm{~m}$ & $1.70 \mathrm{l}$ & $1.59 \mathrm{e}$ & $12.30 \mathrm{j}$ & $12.59 \mathrm{ij}$ & $13.39 \mathrm{~h}-\mathrm{j}$ & $12.76 \mathrm{e}$ \\
\hline Chitosan at $5 \mathrm{~g} / \mathrm{l}$ & $1.79 \mathrm{k}$ & $1.94 \mathrm{~h}$ & $2.09 \mathrm{e}$ & $1.94 \mathrm{c}$ & $13.47 \mathrm{hi}$ & $14.33 \mathrm{gh}$ & 17.24 ef & $15.01 \mathrm{~d}$ \\
\hline Ascobien at $200 \mathrm{ppm}$ & $1.79 \mathrm{k}$ & $1.89 \mathrm{j}$ & $2.00 \mathrm{~g}$ & $1.90 \mathrm{~d}$ & $15.02 \mathrm{~g}$ & 17.50 ef & $17.87 \mathrm{de}$ & $16.79 \mathrm{c}$ \\
\hline Humic acid at $5 \mathrm{~m} / \mathrm{l}$ & $2.02 \mathrm{f}$ & $2.33 \mathrm{~b}$ & $2.47 \mathrm{a}$ & $2.27 \mathrm{a}$ & 17.07 ef & 19.18 bc & $21.03 \mathrm{a}$ & $19.09 \mathrm{a}$ \\
\hline Glutamic acid at $200 \mathrm{ppm}$ & $1.92 \mathrm{i}$ & $2.14 \mathrm{~d}$ & $2.27 \mathrm{c}$ & $2.11 \mathrm{~b}$ & $16.44 \mathrm{f}$ & $18.63 \mathrm{~cd}$ & $19.85 \mathrm{~b}$ & $18.30 \mathrm{~b}$ \\
\hline Mean & $1.81 \mathrm{c}$ & $1.97 \mathrm{~b}$ & $2.11 \mathrm{a}$ & & $14.86 \mathrm{c}$ & $16.44 \mathrm{~b}$ & $17.87 \mathrm{a}$ & \\
\hline
\end{tabular}

carbohydrates \% in leaves of chia plants. However, the best results of these parameters by the treatment of humic acid at $5 \mathrm{ml} / \mathrm{l}$ followed descending by 200 ppm glutamic acid compared to control plants in the two seasons. Besides, zinc at 200ppm sprayed plants showed to be the most effective of aforementioned parameters in $1^{\text {st }}$ and $2^{\text {nd }}$ seasons. Generally, the combined treatment between humic acid combined zinc concentration at $200 \mathrm{ppm}$ scored the highest values of abovementioned parameters when compared to control and others in the two seasons. In addition, using the combinations between humic acid combined zinc concentration at $100 \mathrm{ppm}$ or glutamic acid combined zinc concentration at 200 ppm resulted highly increases of these parameters as compared with control in $1^{\text {st }}$ and $2^{\text {nd }}$ seasons. In contrast, the lowest values of these parameters were recorded by the control, (without any addition) in both seasons. The aforementioned results of humic acid concerning. chemical composition are in parallel with those obtained Ibrahim and Helaly (2017) illustrated that, the better, chemical constituents of seeds and as well as trigonelline content in seeds could be obtained by spraying humic acid at 2 l/feddan level on fertilized fenugreek plants with NK at $75 \%$ of recommended rate. While increases chlorophyll levels as a result of chitosan application are in agreement with findings of Malekpoor et al. (2016) on Ocimum basilicum and Salachna et al. (2017) on Verbena bonariensis.

The results of amino acids are in accordance with the findings of Maryam et al. (2014) on Ocimum basilicum, L., Mohamed et al. (2015) on Ocimum basilicum, L. cv. Genovese and Mohamed et al. (2016) on Ocimum basilicum L. cV. Genovese. Mahdy et al. (2019) on roselle plant declared that, high values of chemical constituents could be obtained under high level of amino acid (1000 ppm).

Additionally, Orlita et al. (2008) on Ruta graveolens, Yin et al. (2012) on Majorana 
vulgare, El-Bassiony et al. ( 2014) on fennel, Mehregan et al. (2017) on Stevia rebaudiana and El-Khateeb et al. (2017) on Majorana hortensis. Afifi et al. (2018) concluded that chitosan at the rate of $200 \mathrm{ppm}$ gave high growth, yield and its components as well quality of snap bean.

The abovementioned results of micronutrients are nearly similar to those obtained by Yadegari (2015) on borago, thyme and marigold and Abou-Shleell (2017) on Moringa olifera. Ghatas and Mohamed (2018) illustrated that, spray Cymbopgon citratus plants with $\mathrm{Zn}$ four times a year enhance the growth, essential oil yield and constituents and some chemical constituents of this plant.

\section{Fixed oil percentage:}

Data presented in Table (9) indicate that fixed oil percentage, of chia was more affected by using applied treatments of safety growth stimulants and zinc as well as their combinations as compared to control plants in the first and second seasons. In this concern, humic acid at $5 \mathrm{ml} / \mathrm{l}$ or zinc at 200 ppm significantly scored the maximum values of fixed oil percentage/plant, in both seasons. However, the highest seeds oil percentage (32.11 and 32.52) were recorded by the combined treatment between humic acid and zinc at $200 \mathrm{ppm}$, followed the combined treatment between glutamic acid and zinc at 200 ppm (29.75 and 30.03) in the first and second seasons, respectively. Furthermore, using the combined treatment of humic acid and zinc at 100 ppm ranked the third value in this respect. The lowest value of chia oil percentage per plant was produced by un-treated control plants in the two seasons. Humic acid (HA) is a promising natural resource to be utilized as an alternative for fertilizers to improve crop production (Nikbakht et al., 2008). Humic substances (HS) have beneficial effects on plant growth, nutrient uptake, root development, yield, and plant photosynthesis which reflected in oil production (Nardi et al., 2002). Whereas increasing essential oil percentage due to humic acid applications are in harmony with Hendawy et al. (2015) on Mentha piperita var. citrata and Jamali et al. (2015) on basil plants and Tadayyon (2017) on Guizotia abyssinica. Regarding the effect of chitosan, Orlita et al. (2008) on Ruta graveolens and Massoud et al. (2016) on Coriandrum sativum reported increases in essential oil productivity by chitosan treatments. Ibrahim and Helaly (2017) illustrated that, the better fixed oil production, chemical constituents of seeds and as well as trigonelline content in seeds could be obtained by spraying humic acid at $2 \mathrm{l} /$ feddan level on fertilized fenugreek plants with NK at $75 \%$ of recommended rate.

Mahdy et al. (2019) on roselle plant declared that, the high values of fixed oil per plant and fixed oil yield) could be obtained under high level of amino acid (1000 ppm) and combined with third level of cytokinin (60 ppm).

\section{Fixed oil compositions of chia (Salvia hispanica L.) seeds:}

Table (10) and Figs. (1-4) declare the data belonging to the effect of different treatments of growth stimulants and zinc i.e. control (tap water), ascobien at 200 ppm with $\mathrm{Zn}$ at $200 \mathrm{ppm}$ humic acid at $5 \mathrm{~m} / \mathrm{l}$ with $\mathrm{Zn}$ at $200 \mathrm{ppm}$, glutamic acid at $200 \mathrm{ppm}$ with $\mathrm{Zn}$ at $200 \mathrm{ppm}$ on the qualitative of the fixed oil compositions of chia (Salvia hispanica L.) seeds. The fixed oil composition of chia produced seven components were identified, i.e. lauric acid, myristic acid, pentadecanoic acid, palmitic acid, oleic acid, linoleic acid and $\alpha$-linolenic acid.

The main component was $\alpha$-linolenic acid (37.28 to 39.72\%). The major components were $\alpha$-linolenic acid (37.28 to $39.72 \%$ ), linoleic acid (29.86 to $32.02 \%$ ), oleic acid (15.95 to $17.62 \%)$ and palmitic acid (3.12 to 6.96\%). Moreover, the combination treatments of humic acid at 5 $\mathrm{m} / \mathrm{l}$ with $\mathrm{Zn}$ at 200ppm gave the maximum values of $\alpha$-linolenic acid as (39.72\%) followed by the combined treatment of glutamic acid at $200 \mathrm{ppm}$ with Zn at 200 
Table 9. Effect of some safety growth stimulant treatments, zinc concentrations and their combination treatments on fixed oil \% of chia (Salvia hispanica L.) plant, during 2018-2019 and 2019-2020 seasons.

\begin{tabular}{lccccccccc}
\hline & \multicolumn{8}{c}{ Zn concentration (ppm) (B) } \\
$\begin{array}{l}\text { Safety growth stimulants } \\
\text { (A) }\end{array}$ & $\mathbf{0 . 0}$ & $\mathbf{1 0 0 . 0}$ & $\mathbf{2 0 0 . 0}$ & Mean & $\mathbf{0 . 0}$ & $\mathbf{1 0 0 . 0}$ & $\mathbf{2 0 0 . 0}$ & Mean \\
& \multicolumn{7}{c}{$\mathbf{1}^{\text {st }}$ season } \\
\hline Control (tap water) & $19.21 \mathrm{~h}$ & $23.07 \mathrm{f}$ & $25.25 \mathrm{e}$ & $22.51 \mathrm{~d}$ & $18.48 \mathrm{i}$ & $22.93 \mathrm{~g}$ & $24.97 \mathrm{f}$ & $22.13 \mathrm{~d}$ \\
Chitosan at $\mathbf{5}$ g/l & $20.69 \mathrm{~g}$ & $26.35 \mathrm{~d}$ & $27.89 \mathrm{c}$ & $24.98 \mathrm{c}$ & $21.93 \mathrm{gh}$ & $26.88 \mathrm{de}$ & $27.56 \mathrm{~cd}$ & $25.46 \mathrm{c}$ \\
Ascobien at $\mathbf{2 0 0} \mathbf{~ p p m}$ & $22.27 \mathrm{f}$ & $24.75 \mathrm{e}$ & $27.47 \mathrm{c}$ & $24.83 \mathrm{c}$ & $21.32 \mathrm{~h}$ & $27.62 \mathrm{~cd}$ & $27.26 \mathrm{de}$ & $25.40 \mathrm{c}$ \\
Humic acid at $\mathbf{5 ~} \mathbf{~ m / l}$ & $25.48 \mathrm{de}$ & $29.27 \mathrm{~b}$ & $32.11 \mathrm{a}$ & $28.95 \mathrm{a}$ & $27.26 \mathrm{de}$ & $28.81 \mathrm{bc}$ & $32.52 \mathrm{a}$ & $29.53 \mathrm{a}$ \\
Glutamic acid at $\mathbf{2 0 0} \mathbf{~ p p m}$ & $24.44 \mathrm{e}$ & $27.56 \mathrm{c}$ & $29.75 \mathrm{~b}$ & $27.25 \mathrm{~b}$ & $26.03 \mathrm{ef}$ & $28.07 \mathrm{~cd}$ & $30.03 \mathrm{~b}$ & $28.05 \mathrm{~b}$ \\
Mean & $22.42 \mathrm{c}$ & $26.20 \mathrm{~b}$ & $28.49 \mathrm{a}$ & & $23.00 \mathrm{c}$ & $26.86 \mathrm{~b}$ & $28.47 \mathrm{a}$ & \\
\hline
\end{tabular}

Table 10. Effect of different treatments on fixed oil composition of chia (Salvia hispanica L.) plant, during the second season 2019-2020.

\begin{tabular}{|c|c|c|c|c|c|}
\hline \multirow[b]{2}{*}{$\begin{array}{l}\text { Peal } \\
\text { No. }\end{array}$} & \multirow[b]{2}{*}{$\begin{array}{c}\text { Component } \\
\text { name }\end{array}$} & \multicolumn{4}{|c|}{ Area \% } \\
\hline & & $\begin{array}{c}\text { Control } \\
\text { (tap water) }\end{array}$ & $\begin{array}{l}\text { Ascobien at } 200 \mathrm{ppm} \\
+ \text { Zn at } 200 \mathrm{ppm}\end{array}$ & $\begin{array}{c}\text { Humic acid at } 5 \mathrm{~m} / \mathrm{l}+ \\
\mathrm{Zn} \text { at } 200 \mathrm{ppm}\end{array}$ & $\begin{array}{l}\text { Glutamic acid at } 200 \\
\text { ppm }+\mathrm{Zn} \text { at } 200 \text { ppm }\end{array}$ \\
\hline 1 & Lauric acid & 1.96 & 0.54 & 0.56 & 0.88 \\
\hline 2 & Myristic acid & 1.14 & 0.59 & 0.73 & 0.99 \\
\hline 3 & Pentadecanoic acid & 2.08 & 2.10 & 0.85 & 0.90 \\
\hline 4 & Palmitic acid & 3.12 & 5.86 & 6.96 & 6.15 \\
\hline 5 & Oleic acid & 15.95 & 17.57 & 17.62 & 17.13 \\
\hline 6 & Linoleic acid & 29.86 & 30.62 & 32.02 & 31.12 \\
\hline 7 & $\alpha$-linolenic acid & 37.28 & 38.33 & 39.72 & 38.95 \\
\hline- & Total identified & 91.39 & 95.61 & 98.46 & 96.12 \\
\hline$*$ & Unknown & 8.61 & 4.39 & 1.54 & 3.88 \\
\hline & Total & 100.00 & 100.00 & 100.00 & 100.00 \\
\hline
\end{tabular}

ppm as (38.95\%) and the combined treatment of ascobien at $200 \mathrm{ppm}$ with $\mathrm{Zn}$ at $200 \mathrm{ppm}(38.33 \%)$ as compared to control (37.28\%) . Meanwhile, different treatments caused increases in the percentage of linoleic acid from 29.86 in control to $32.02 \%$ of the combination treatments of humic acid at 5 $\mathrm{m} / \mathrm{l}$ with $\mathrm{Zn}$ at $200 \mathrm{ppm}$. Furthermore, the combined treatment humic acid with $\mathrm{Zn}$ at $200 \mathrm{ppm}$ gave the maximum values of oleic acid (17.62\%) followed by the combined treatment of ascobien at $200 \mathrm{ppm}$ with Zn at 200 ppm (17.57\%). Additionally, the highest values of palmitic acid by the combined treatment humic acid with Zn at 200 ppm and the combined treatment glutamic acid at 200 ppm with Zn at 200 ppm (6.96 and $6.15 \%$, respectively). The major components of chia oil were stated by various studies like Ayerza and Coates (2004) found that the majors component were $\alpha$-linolenic (63.2\%), linoleic (18\%), oleic (3.4\%), palmitic (7.25\%) and stearic (3.4\%). Segura-Campos et al. (2014) stated that chia oil contains $\alpha$ linolenic (68.52\%), linoleic (20.40\%), oleic (2.43\%), palmitic $(7.74 \%)$ and stearic (0.29\%) and Silva et al. (2016) studied quantification of fatty acids in the chia seed oils obtained with different solvents and stated that $\alpha$-linolenic arranged (61.48 - 

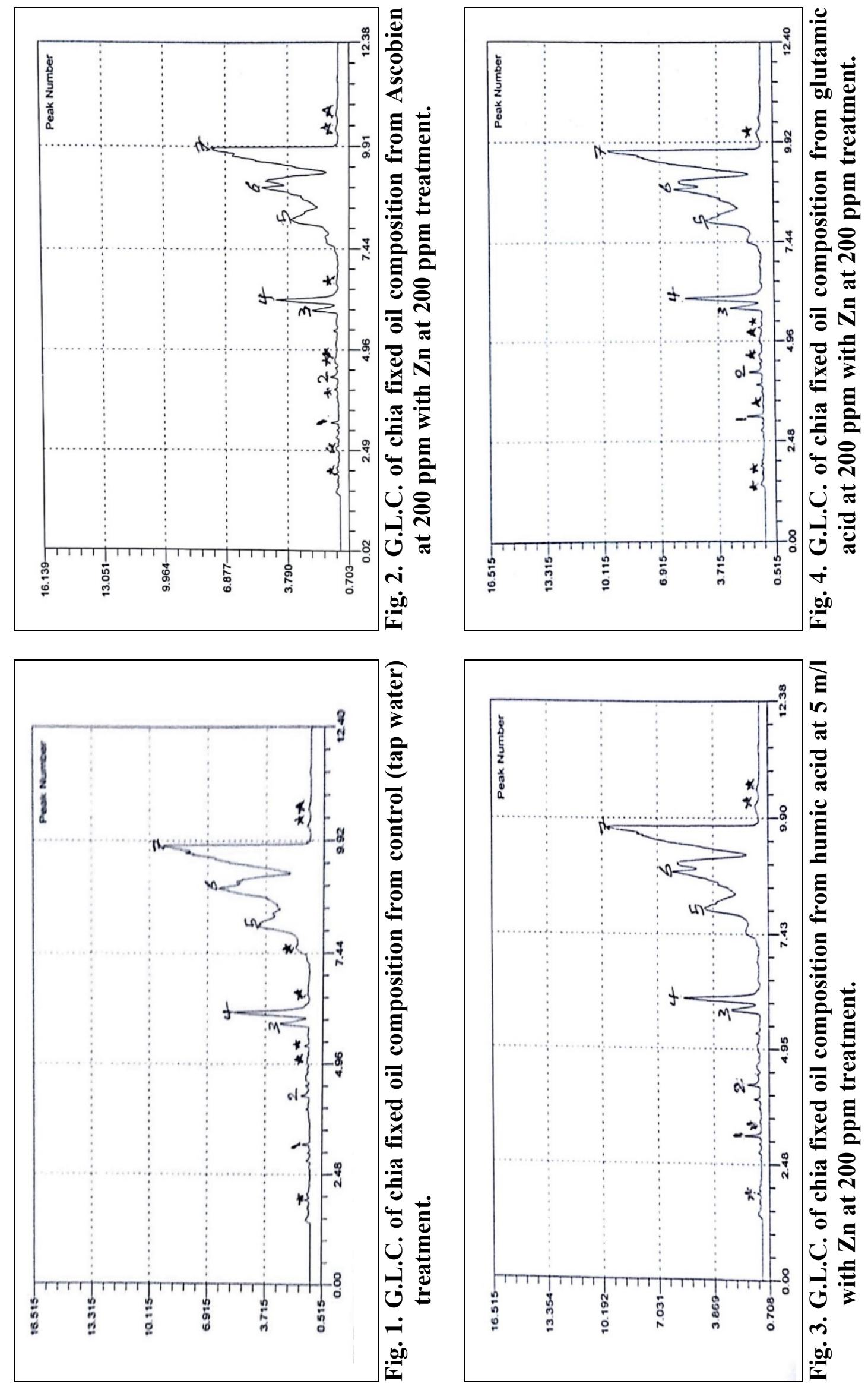
62.92\%), linoleic $(18.10-19.76 \%)$, oleic (6.9 - 6.87\%), palmitic (9.13 - 9.95\%) and stearic (2.92 - 2.99\%). Moghith (2019) declared that, the fixed oil composition of chia produced 23 compounds were identified, the main components were $\alpha$ linolenic acid (54.96 to 63.23\%) linoleic acid (15.82 to $21.36 \%)$, oleic acid (6.19 to $15.86 \%$ ) and palmitic acid (6.30 to $8.15 \%$ ).

\section{CONCLUSION}

Conclusively, from the obtained results, it could be recommended that the combinations of humic acid at $5 \mathrm{~m} / \mathrm{l}$ with $\mathrm{Zn}$ at $200 \mathrm{ppm}$ could be used to improve growth, seeds yield, chemical constituents, fixed oil productivity and fixed oil constituents of chia (Salvia hispanica L.) plant.

\section{REFERENCES}

Abdossi, V. and Danaee, E. (2019). Effects of some amino acids and organic acids on enzymatic activity and longevity of Dianthus caryophyllus cv. Tessino at Pre-harvest stage. Journal of Ornamental Plants, 9 (2):93-104.

Abou-Shleell, M.K.K. (2017). Botanical Studies on Moringa Plant: Ph.D. Thesis, Fac. Agric., Moshtohor, Benha. Univ., Egypt., 150 p.

Adib, S.S.; Dehaghi, M.A.; Rezazadeh, A. and Naji, A.M. (2020). Evaluation of sulfur and foliar application of $\mathrm{Zn}$ and $\mathrm{Fe}$ on yield and biochemical factors of cumin (Cuminum cyminum L.) under irrigation regimes. Journal of Herbmed. Pharmacology, 9(2):1-10.

Afifi, S.T.; Shalata, A.A.A. and Kiera, R.M.M. (2018). Effect of compost rates and spraying with some biostimulant substances on growth, yield and quality of snap bean, J. Plant Production, Mansoura Univ., 9(7):601-607.

Aiyafar, S.; Poudineh, H.M. and Forouzandeh, M. (2015). Effect of humic acid on qualitative and quantitative characteristics and essential oil of black cumin (Nigella sativa L.) under water deficit stress. DAV. Int. J. Sci., 4:89-102.

Akbari, I. and Gholam, A. (2016). Evaluation of mycorrhizal fungi, vermicompost and humic acid on essence yield and root colonization of fennel. Iranian Journal of Field Crops Research, 13(4):840-853.

Amberger, A. (1974). Micro-nutrients, dynamics in the soil and function in plant metabolism, I. Iron. Proc. Egypt. Bot. Soc. Workshop 1, Cairo, pp. 81-90.

Arancon, N.Q.; Edwards, C.A.; Lee, S. and Byrne, R. (2006). Effects of humic acids from vermicomposts on plant growth. Eur. J. Soil. Biol., 42:65-69.

Ariafar, S. and Forouzandeh, M. (2017). Evaluation of humic acid application on biochemical composition and yield of black cumin under limited irrigation condition. Bulletin de la Société Royale des Sciences de Liège, 86(1):13-24.

Awad, M.Y.M. (2016). Poultry manure and humic acid foliar applications impact on caraway plants grown on a clay loam. J. Soil Sci. and Agric. Eng., Mansoura Univ., 7(1):1-10.

Ayerza, R. (2013). Seed composition of two chia (Salvia hispanica L.) genotypes which differ in seed color. Emirates Journal of Food and Agriculture, 25:495500 .

Ayerza, R. and Coates, W. (2000). Dietary levels of chia influence on yolk cholesterol, lipid content and fatty acid composition, for two strains of hens. Poultry Science., 78:724-739.

Ayerza, R. and Coates, W. (2004). Composition of chia (Salvia hispanica) grown in six tropical and subtropical ecosystems of South America. Tropical Science, 44:131-135.

Ayerza, R. and Coates, W. (2009). Some quality components of four chia (Salvia hispanica L.) genotypes grown under tropical coastal desert ecosystem 
conditions. Asian J. Plant Sci., 8(4):301307.

Behzad, S. (2011). Effects of amino acids and irrigation interrupted on some characteristics in flixweld (Descurainia sophia L.). Proc. International Conference on Biology, Environment and Chemistry., IACSIT Press, Singapore, 1:375-378.

Berlyn, G.P. and Russo, R.O. (1990). The use of organic biostimulants to promote root growth. Below Ground Ecol., 2:1213.

Black, C.A.; Evans, D.O.; Ensminger, LE.; White, J.L.; Clark, F.E. and Dinauer, R.C. (1982). Methods of Soil Analysis. Part 2. Chemical and Microbiological Properties. $2^{\text {nd }}$ Ed. Soil Sci., Soc. of Am. Inc. Publ., Madison, Wisconsin, U. S.A., $1159 \mathrm{p}$.

Bresson, J.L.; Flynn, A.; Heinonen, M.; Hulshof, K.; Korhonen, H.; Lagiou, P.; Løvik, M.; Marchelli, R.; Martin, A.; Moseley, B.; Przyrembel, H.; Salminen, S.; Strain, J.J.; Strobel, S.; Tetens, I.; Berg, H.; Loveren, H. and Verhagen, H. (2009). Opinion on the safety of chia seeds (Salvia hispanica L.) and ground whole chia seeds as a food ingredient. The European Food Safety Authority Journal, 996:1-26.

Cahill, J.P. and Provance, M.C. (2002). Genetics of qualitative traits in domesticated chia (Salvia hispanica L.). Journal of Heredity, 93(1):52-55.

Chandler, H. (1982). Zinc as nutrient for plants. Bot. Hag., 98:625-646.

Chaplin, M.F. and Kennedy, J.F. (1994). Carbohydrate Analysis, 2 ${ }^{\text {nd }}$ ed. Oxford University Press, New York., 344 p.

Coorey, R.; Grant, A. and Jayasena, V. (2012). Effect of chia flour incorporation on the nutritive quality and consumer acceptance of chips. Journal of Food Research, 1:85-95.
Datir, R.B.; Apparao, B.J. and Laware, S.L. (2012). Application of amino acid chelated micronutrients for enhancing growth and productivity in chili (Capsicum annum L.). Plant Sciences Feed, 2(7):100-105.

Duncan, D.B. (1955). Multiple range and multiple F test. Biometrics, 11:1-42.

El-Bassiony, A.M.; Fawzy, Z.F.; Zaki, M.F. and El-Nemr, M.A. (2014). Increasing productivity of two sweet fennel cultivars by foliar spraying of some bio and organic compounds. Middle East Journal of Applied Sci., 4(4):794-801.

El-Khateeb, M.A.; El-Attar, Asmaa B. and Nour, R.M. (2017). Application of plant biostimulants to improve the biological responses and essential oil production of marjoram (Majorana hortensis, Moench) plants. Middle East J. Agric. Res., 6:928941.

El-Shayeb, N.S.A.; Abo El-Soud, I.H. and El-Shal, S.A (2015). Effect of different levels of chemical fertilization and humic acid on Salvia officinalis L. plants. Egypt. J. of Appl. Sci., 30(11):727-758.

Foyer, C.H. (1993). Ascorbic acid. In. R.G. Alscher and J.L. Hess (eds.) Antioxidants in Higher Plants. CRC Press, Inc. Florida, pp. 31-58.

Frankenberger, W.T. and Arshad, M. (1995). Phytohormones in Soils: Microbial Production and Function. Marcel and Deckker, New York, 503 p.

Ghatas, Y.A.A. and Mohamed, Y.F.Y. (2018). Influence of mineral, micronutrients and lithovit on growth, oil productivity and volatile oil constituents of Cymbopogon citratus L. Plants. Middle East J. Agric. Res., 7(1):162-174.

Gornik, K.; Grzesik, M. and Duda, B.R. (2008). The effect of chitosan on rooting of gravevine cuttings and on subsequent plant growth under drought and temperature stress. J. Fruit and Ornamental Plant Res., 16:33-34. 
Graves, A.; Matthews, R. and Waldie, K. (2004). Low external input technologies for livehood improvement in subsistence agriculture. Adv. Agron., 82:473-555.

Guan, Y.H.J.; Xian, W. and Chenia, S. (2009). Seed priming with chitosan improves maize germination and seedling growth in relation to physiological changes under low temperature stress. J. Zhejiang Univ. Sci.,10:427-433.

Hadwiger, L.A. (2013). Multiple effects of chitosan on plant systems: solid science or hype. Plant Sci., 208:42-49.

Haj Seyed Hadi, S.M.R.; Darzi, M.T.; Ghandehari, Z. and Riazi, G.H. (2011). Effects of vermicompost and amino acids on the flower yield and essential oil production from Matricaria chamomila L. J. Med. Plants Res., 5(23):5611-5617.

Hendawy, F.S.; Hussein, M.S.; El-Gohary, A.E. and Ibrahim, M.A. (2015). Effect of foliar organic fertilization on the growth, yield and oil content of Mentha piperita var. citrata. Asian Journal of Agric. Res., 9:237-248.

Horneck, D.A. and Hanson, D. (1998). Determination of Potassium and Sodium by Flame Emission Spectrophotometry. In Kolra, Y.P. (ed.), Hand Book of Reference Methods for Plant Analysis. Taylor and Francis Group, LLC., pp. 153-155.

Horneck, D.A. and Miller, R.O. (1998). Determination of Total Nitrogen in Plant Tissue. In Kolra, Y.P. (ed.), Hand Book of Reference Methods for Plant Analysis, Taylor and Francis Group, LLC., 73 p.

Hucker, T. and Catroux, G. (1980). Phosphorus in sewage ridge and animal's wastes slurries. Proceeding of the EEC Seminar, Haren (Gr): Gromingen, 12-13 June, Netherlands.

Hussein, M.S. (2013). Effect of amino acids application on production, volatile oil and chemical composition of chamomile cultivated in saline soil at Sinai. J. Appl. Sci. Res., 9(4):3006-3021.
Ibrahim, F.R. and Helaly, A.A.E. (2017). Growth and productivity response to nitrogen, potassium and humic acid of fenugreek (Trigonella foenum-graecum L.) plant. Middle East J. Agric. Res., 6:1526-1535.

Inskeep, W.P. and Bloom, P.R. (1985). Extinction coefficients of chlorophyll a \& b in NN-dimethylformade and $80 \%$ acetone. Plant Physiol., 77:483-485.

Ixtaina, V.Y.; Nolasco, S.M. and Tomas, M.C. (2008). Physical properties of chia (Salvia hispanica L.) seeds. Industrial Crops and Products, 28(3):286-293.

Jackson, M.L. (1973). Soil Chemical Analysis. Prentice-Hall of Indian Private, New Delhi, India, 478 p.

Jamali, Z.S.; Astaraei, A.R. and Emami, H. (2015). Effect of humic acid, compost and phosphorus on growth characteristics of basil herb and concentration of micro elements in plant and soil. J. Sci. and Tech., 6(2):187-205.

Mahdy, H.A.A.; Mubarak, D.M.; El-Azab, M.E.; Mohammed, K.A.S. and Abd ElRheem, K.M. (2019). Effect of foliar spraying with amino acid and cytokinin on growth, yield quality and quantity of nutritional status of roselle plants, Bioscience Research, 16(1):102-109.

Malekpoor, F.; Pirbalouti, A.G. and Salimi, A. (2016). Effect of foliar application of chitosan on morphological and physiological characteristics of basil under reduced irrigation. Research on Crops, 17(2):354-359.

Marschner, H. (2012). Mineral Nutrition of Higher Plants. Academic Press, London, UK, pp. 347-364.

Maryam, S.; Mohammad, R.H. and Mohammad, T.D. (2014). Effects of amino acids and nitrogen fixing bacteria on quantitative yield and essential oil content of basil (Ocimum basilicum). Agric. Sci. Dev., 3(8):265-268. 
Massoud, H.Y.; Abdelkader, H.; ElGhadban, E.A. and Mohammed, R.M. (2016). Improving growth and active constituents of (Coriandrum sativum 1.) plant using some natural stimulants under different climate conditions. J. Plant Production, Mansoura Univ., 7(6):659669.

Mehregan, M.; Mehrafarin, A.; Labbafi, M. and Naghdi Badi, H. (2017). Effect of different concentrations of chitosan biostimulant on biochemical and morphophysiological traits of stevia plant (Stevia rebaudiana Bertoni). J. of Med. Plants, 16(62):169-181.

Moghith, W.M.A. (2019). studies on Growth and Productivity of Chia Plant (Salvia hispanica L.) Under Egyptian Conditions, Ph.D. Thesis, Fac. Agric., Benha Univ, Egypt, 198 p.

Mohamed, S.M.; Abou El-Ghait, E.M.; Ghatas, Y.A.; El Shayieb, N.M. and Shahin, A.A.S. (2015). Effect of some fertilizers on improving growth and oil productivity of basil (Ocimum basilicum, L.) cv. Genovese plant. Egypt. J of Appl. Sci., 30(6):384-399.

Mohamed, Y.F.Y.; Zewail, R.M.Y. and Ghatas, Y.A.A. (2016). The role of boron and some growth substances on growth, oil productivity and chemical characterization of volatile oils in basil (Ocimum basilicum L.) cv. Genovese. Journal of Horticultural Science \& Ornamental Plants, 8(2):108-118.

Nardi, S.; Pizzeghelloa, D.; Muscolob, A. and Vianello, A. (2002). Physiological effects of humic substances on higher plants. Soil Biol. Biochem., 34:15271536.

Nasiri, Z.; Khalighi, A. and Matlabi, E. (2015). The effect of humic acid, fulvic acid, and kristalon on quantitative and qualitative characteristics of geranium. International Journal of Biosciences, 6(5): 34-41.
Nikbakht, A.; Kafi, M.; Babalar, M.; Xia, Y.P.; Luo, A. and Etemadi, N. (2008). Effect of humic acid on plant growth, nutrients uptake and postharvest life of gerbera. J. Plant Nutr., 31:2155-2167.

Noctor, G. and Foyer, C.H. (1998). Ascorbate and glutathione: keeping active oxygen under control. Annu. Rev. of Plant Physiol. and Plant Mol. Biol., 49:249-279.

Ojeda-Barrios, D.L.; Perea-Portillo, E.; Hernández-Rodríguez, O.A.; ÁvilaQuezada, G.; Abadía, J. and Lombardini, L. (2014). Foliar fertilization with zinc in pecan trees. HortScience, 49(5):562-6.

Omer, E.A.; Said-Al Ahl, H.A.H.; El Gendy, A.G.; Shaban, K.A. and Hussein, M.S. (2013). Effect of amino acids application on production, volatile oil and chemical composition of chamomile cultivated in saline soil at Sinai. J. Appl. Sci. Res., 9(4):3006-3021.

Orlita, A.; Gorycka, M.S; Paszkiewicz, M.; Malinski, E.; Kumirska, J.; Sied, M.; Stepnowski, P. and Lojkowska. E. (2008). Application of chitin and chitosan as elicitors of coumarins and furoquinolone alkaloids in Ruta graveolens L. (common rue). J. Biotech. and Applied Biochem., 51(2):91-96.

Peiretti, P.G. and Gai, F. (2009). Fatty acid and nutritive quality of chia (Salvia hispanica L.) seeds and plant during growth. Animal Feed Science and Technology, 148 (2-4):267-275.

Peiretti, P.G. and Meineri, G. (2008). Effects on growth performance, carcass characteristics, and the fat and meat fatty acid profile of rabbits fed diets with chia (Salvia hispanica L.) seed supplements. Meat Science, 80(4):1116-1121.

Pereira, M.M.A.; Morais, L.C.; Marques, E.A.; Martins, A.D.; Cavalcanti, V.P.; Rodrigues, F.A.; Gonçalves, W.M.; Blank, A.F.; Pasqual, M. and Dória, J. (2019). Humic substances and efficient microorganisms: elicitation of medicinal 
plants- a review. Journal of Agricultural Science; 11(7):268-280.

Rahimi, A.; Mehrafarin, A.; Badi, H.N. and Sigaroodi, F.K. (2013). Effects of biostimulators and bio-fertilizers on morphological traits of basil (Ocimum basilicum L.). Annals of Biological Research, 4(5):146-151.

Rai, V.K. (2002). Role of amino acids in plant responses to stresses. Biologia Plantarum, 45(4):481-487.

Reyes-Caudillo, E.; Tecante, A. and Valdivia-Lopez, M.A. (2008). Dietary fibre content and antioxidant activity of phenolic compounds present in Mexican chia (Salvia hispanica L.) seeds. Food Chemistry, 107(2):656-663.

Saeid Zehtab, S.; Behrouznajhad, S. and Ghassemi-Golezani, K. (2012). Effects of foliar application of $\mathrm{Fe}$ and $\mathrm{Zn}$ on seed yield and mucilage content of Psyllium at different stages of maturity. Proc. International Conference on Environment, Agriculture and Food Sciences (ICEAFS'2012) August, 11-12, 2012, Phuket, Thailand.

Salachna, P.; Byczyńska, A.; Jeziorskaand, I. and Udycz, E. (2017). Plant growth of Verbena bonariensis L. after chitosan, gellan gum or iota-carrageenan foliar applications. World Scientific News, 62:111-123.

Segura-Campos, M.R.; Ciau-Solís, N.; Rosado-Rubio, G.; Chel-Guerrero, L. and Betancur-Ancona, D. (2014). Physicochemical characterization of chia (Salvia hispanica) seed oil from Yucatán. México Agricultural Sciences, 5:220226.

Silva, C.; Garcia, V.A.S. and Zanette, C.M. (2016). Chia (Salvia hispanica L.) oil extraction using different organic solvents: oil yield, fatty acids profile and technological analysis of defatted meal. International Food Research Journal, 23(3):998-1004.

Smirnoff, N. (2005). Ascrobate, tocopherol and carotenoids: mestabolism, pathway engineering and function. In: $\mathrm{N}$. Smirnoff, (ed.), Antioxidants and Reactive Oxygen Spexies in Plants, Blackwell Publishing Ltd, Oxford, UK, pp. 53-86.

Snedecor, G.W. and Cochran, W.G. (1989). Statistical Methods, $8^{\text {th }}$ ed. Iowa State University Press, Ames, 503 p.

Stahl, E.E. (1967). Thin Layer Chromatography, A Laboratory Hand Book. Springer Verlag, New York, pp. 14-37.

Tadayyon, A.; Beheshti, S. and Pessarakli, M. (2017). Effects of sprayed humic acid, iron and zinc on quantitative and qualitative characteristics of niger plant (Guizotia abyssinica L.). Journal of Plant Nutrition, 40:1644-1650.

Taiz, L. and Zeiger, E. (2002). Plant Physiology, $3^{\text {rd }}$ ed. Sinauer Associates Inc., Sunderland, 690 p.

Yadegari, M. (2015). Foliar application of micronutrients on essential oils of borago, thyme and marigold. Journal of Soil Science and Plant Nutrition, 15(4):949-964.

Yassen, A.A.; Abou El-Nour, E.A.A and Shedeed, S. (2010). Response of wheat to foliar spray with urea and micronutrients. J. Amer. Sci., 6(9): 14-22.

Yin, H.L.; Fretté, X.C.; Christensen, L.P. and Grevsen, K. (2012). Chitosan oligosaccharides promote the content of polyphenols in Greek oregano (Majorana vulgare ssp. hirtum). J. Agric. Food Chem., 60(1):136-143.

Zanqui, A.B.; Morais, D.R.; Silva, C.M.; Santos, J.M.; Chiavelli, L.U.R.; Bittencourt, P.R.S; Eberlin, M.N.; Visentainer, J.V.; Cardozo-Filho, L. and Matsushita, M. (2015). Subcritical extraction of Salvia hispanica L. oil with n-propane: composition, purity and oxidation stability as compared to the oils obtained by conventional solvent extraction methods. Journal of The Brazilian Chemical Society, 26:282-289. 


\title{
تأثير بعض منثطات النمو الامنة والزنتك على النموومحصول البذور والمحتوى الكيماوى وإنتاجية

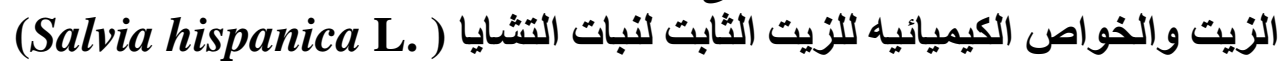

\author{
يسرى فهمى يوسف محمد و ياسر عبد الفتاح عبد العاطي غطاس

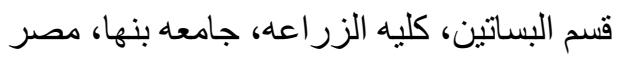

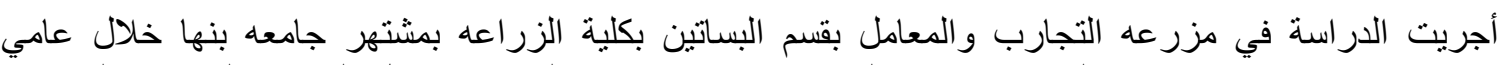

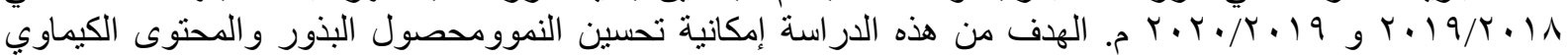

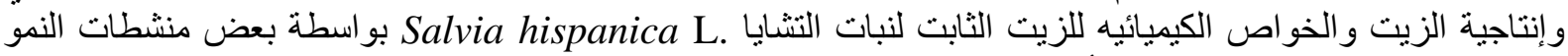

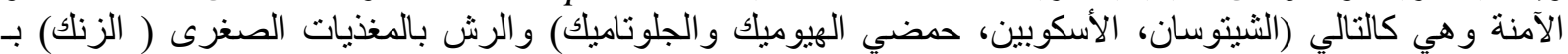

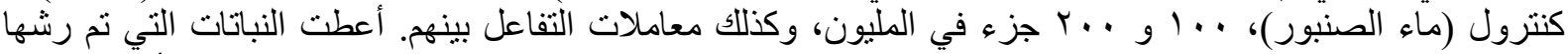

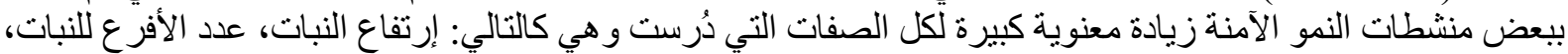

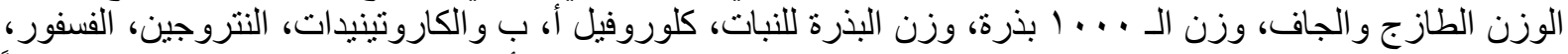

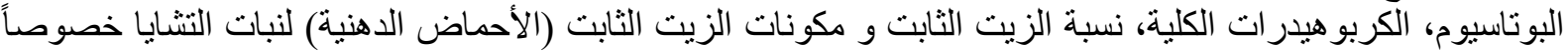

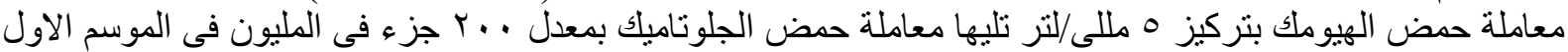

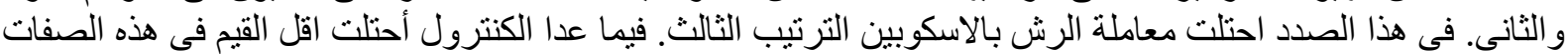

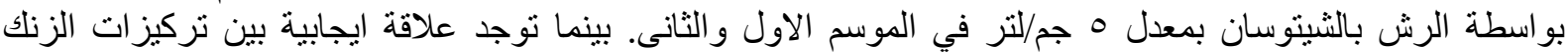

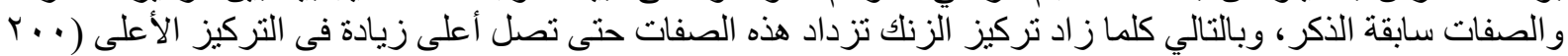

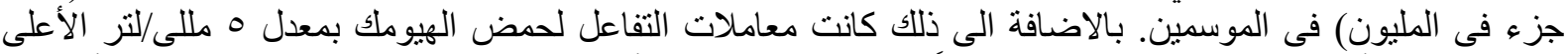

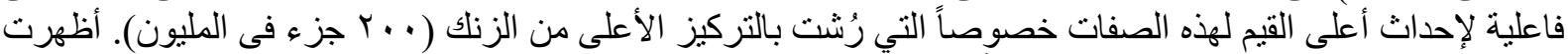

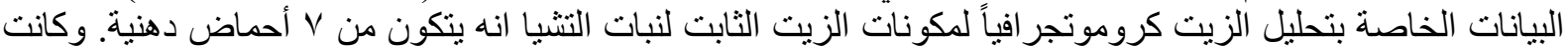

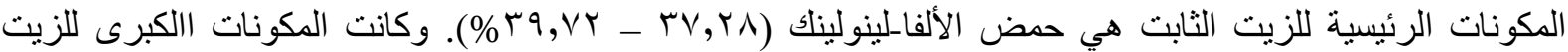

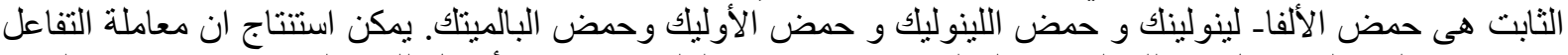

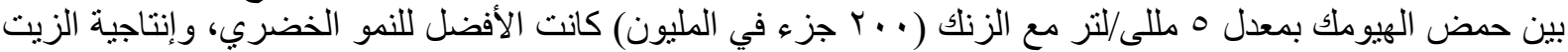

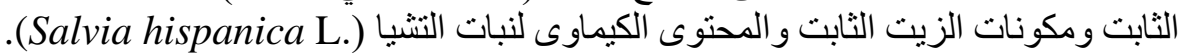

